UNESP - UNIVERSIDADE ESTADUAL PAULISTA FACULDADE DE ODONTOLOGIA DE ARARAQUARA

JULIANA OLIVEIRA GONDIM

EFEITO ANTIBACTERIANO E SUCESSO CLÍNICO/RADIOGRÁFICO DA PASTA DE HIDRÓXIDO DE CÁlCIO ASSOCIADA À CLOREXIDINA COMO MEDICAÇÃO INTRACANAL NO TRATAMENTO DE DENTES DECÍDUOS HUMANOS COM POLPA NECRÓTICA

Tese apresentada ao Programa de PósGraduação em Ciências Odontológicas Área de Odontopediatria - da Faculdade de Odontologia de Araraquara, da Universidade Estadual Paulista, para o Título de Doutor em Ciências Odontológicas.

Orientadora: Profa. Dra. Elisa Maria Aparecida Giro Araraquara 
JULIANA OLIVEIRA GONDIM

\title{
EFEITO ANTIBACTERIANO E SUCESSO CLÍNICO/RADIOGRÁFICO DA PASTA DE HIDRÓXIDO DE CÁLCIO ASSOCIADA À CLOREXIDINA COMO MEDICAÇÃO INTRACANAL NO TRATAMENTO DE DENTES DECÍDUOS HUMANOS COM POLPA NECRÓTICA
}

\author{
COMISSÃO JULGADORA
}

TESE PARA OBTENÇÃO DO GRAU DE DOUTOR

\author{
Presidente e Orientador: Profa. Dra. Elisa Maria Aparecida Giro \\ $2^{\circ}$ Examinador: Profa. Dra. Jaqueline Braga Barbosa \\ $3^{\circ}$ Examinador: Prof. Dr. Célio Percinoto \\ $4^{\circ}$ Examinador: Profa. Dra. Denise Madalena Palomar Spolidório \\ $5^{\circ}$ Examinador: Profa. Dra. Josimeri Hebling
}

Araraquara, 05 de Março de 2010. 


\section{DADOS CURRICULARES}

\section{JULIANA OLIVEIRA GONDIM}

Nascimento 12/08/1977, Fortaleza, CE

Filiação Maria Anita Oliveira Gondim

Francisco Átila de Lira Gondim

1998 - 2002 Graduação em Odontologia pela Faculdade de Farmácia, Odontologia e Enfermagem - Universidade Federal do Ceará

2002 - 2004 Especialização em Odontopediatria pela Associação Brasileira de Odontologia - Secção Ceará - ABO - CE

2002 - 2004 Professora Substituta de Odontopediatria - Faculdade de Farmácia,

Odontologia e Enfermagem - Universidade Federal do Ceará

2005 - 2006 Curso de Pós Graduação em Ciências Odontológicas, Área de Concentração Odontopediatria, nível Mestrado da Faculdade de Odontologia de Araraquara - UNESP

2007 - 2010 Curso de Pós Graduação em Ciências Odontológicas, Área de Concentração Odontopediatria, nível Doutorado da Faculdade de Odontologia de Araraquara - UNESP

2009 Professora Assistente I de Odontopediatria e Ortodontia Universidade Federal do Ceará - Campus Sobral 


\section{Dedico Este trabalho...}

À Deus, que me proporcionou saúde, tranqüilidade, paciência e força. Obrigada por Sua presença constante em minha caminhada.

Aos meus queridos pais, Átila e Anita, meus irmãos, Janaina, Roger e Viviane, pelo amor, compreensão e sacrifícios dispensados para que eu chegasse até aqui. Agradeço por estarem sempre dispostos a me ajudar.

Aos sobrinhos Sophia, Vitor e Helena, a mais nova integrante, que trouxeram muita alegria e harmonia para a nossa família.

Ao meu filhote Matheus, que me dá força e coragem para enfrentar guerreiramente cada obstáculo. Por proporcionar felicidade, mesmo nos momentos de angústia! Agradeço a Deus por sua existência! Amo você!

Ao meu amor, namorado e marido, Jeová, por toda compreensão, carinho, paciência, amor e confiança. Obrigada 
por continuar sendo meu porto seguro, independente da situação. Obrigada também por ter ajudado a concretizar mais este trabalho. Sua participação foi essencial! Agradeço a Deus por você estar em minha vida. Te amo! 


\section{Agradecimentos especiais...}

À minha querida orientadora, Profa. Dra. Elisa Maria Aparecida Giro, pelos ensinamentos, pela compreensão, pela confiança e pelas oportunidades concedidas a minha formação. Além de amiga, um exemplo de profissional dedicada, humilde, responsável e honesta. A você, minha eterna admiração e gratidão.

\section{À Profa. Dra. Denise Madalena Palomari Spolidorio, por} toda amizade, atenção, dedicação, disponibilidade e participação neste trabalho. Obrigada por ter permitido a realização de parte deste trabalho no Laboratório de Microbiologia desta Faculdade.

À querida amiga Débora Lindeza, por toda amizade, alegria, dedicação e participação ativa neste trabalho. Companheira de casa, sala e cozinha. Obrigada por todos os momentos compartilhados. É uma amizade que quero que dure para sempre. 
Á querida amiga Elcilaine Azevedo, por toda amizade, preocupação e carinho. Obrigada pelo apoio, pela hospedagem e pelos momentos de descontração. Amizade eterna.

Aos amigos Nancy Tomoko, Simone Mastrantônio, Camila Fávero e Fabiano Jeremias, pela amizade, por estarem sempre dispostos a me ajudar e por torcerem pelo meu sucesso. Obrigada por sempre transmitirem energia positiva.

À querida Daniele Spirandeli, por todo apoio, carinho, amizade e por continuar, mesmo à distância, torcendo pelo meu sucesso. Obrigada por ajudar a finalizar o atendimento dos pacientes integrantes deste projeto.

Às queridas Juliana Rico e Telma Bedran pela amizade e por toda disposição em me ajudarem, direta ou indiretamente, na parte laboratorial deste trabalho.

À Profa. Dra. Josimeri Hebling pelo apoio e atenção durante esse período de convivência, sempre disposta a ajudar em minha pesquisa. 


\section{Agradecimentos...}

À Faculdade de Odontologia de Araraquara - Universidade Estadual Paulista, representada pelo digníssimo Diretor Prof. Dr. José Cláudio Martins Segalla e pela Vice-Diretora Profa. Dra. Andréia Affonso Barreto Montandon.

Ao Departamento de Clínica Infantil da Faculdade de Odontologia de Araraquara - UNESP, representados pelo Chefe de Departamento Prof. Dr. Luiz Gonzaga Gandini Jr. e pela Vice-Chefe Profa. Dra. Ângela Cristina Cilense Zuanon.

Aos professores da Disciplina de Odontopediatria da Faculdade de Odontologia de Araraquara - UNESP, Ângela Cristina Cilense Zuanon, Cyneu Aguiar Pansani, Elisa Maria Aparecida Giro, Fábio César Braga de Abreu e Lima, Josimeri Hebling, Lourdes Aparecida Martins dos Santos-Pinto e Rita de Cássia Loiola Cordeiro. 
Ao Programa de Pós-Graduação em Ciências Odontológicas da Faculdade de Odontologia de Araraquara - UNESP, representado pelas professoras Dras. Josimeri Hebling (Coordenadora) e Lourdes Aparecida Martins dos Santos-Pinto (Vice-coordenadora).

Aos professores do Programa de Pós-Graduação em Ciências Odontológicas, Áreas de concentração de Odontopediatria, Ortodontia e Dentística Restauradora, pela atenção e ensinamentos.

À Coordenação de Aperfeiçoamento de Pessoal de Nível Superior - CAPES e à Fundação de Amparo à Pesquisa do Estado de São Paulo - FAPESP pela concessão de bolsa de estudo e auxílio pesquisa.

Aos Profs. Drs. Cleslei Fernando Zanelli e Sandro Roberto Valentini, pela contribuição na realização deste projeto e por terem permitido a realização de parte deste trabalho no Laboratório de Biologia Molecular e Celular de Microrganismos da Faculdade de Ciências Farmacêuticas de Araraquara - UNESP. 
À colega Juliana Avaca pela disponibilidade e contribuição na execução da parte laboratorial deste trabalho. Meus imensos agradecimentos.

À amiga Cristiane Duque pela amizade, pelos conhecimentos transmitidos, pela ajuda e pelo estímulo para realização deste trabalho.

À Profa. Mônica Sampaio do Vale pela disponibilidade e pelas sugestões dadas na elaboração deste projeto.

À Profa. Dra. Márcia Pinto Alves Mayer, pela utilização do Laboratório de Microbiologia Oral no Instituto de Ciências Biomédicas da USP - SP. Obrigada pela atenção. Agradeço também a disponibilidade e atenção do técnico de laboratório, Sr. João.

Ao Prof. Dr. Carlos Alberto de Souza Costa por permitir a utilização do Laboratório de Patologia Experimental e Biomateriais desta Faculdade. Obrigada pela atenção. 
Às minhas queridas amigas de doutorado pela amizade, união e ótimo convívio: Nancy, Simone, Cármen e Michele. Obrigada pela amizade de vocês.

À querida Savana. Amiga, obrigada pelo carinho e por toda amizade.

Aos meus amigos de Pós-Graduação: Andreza, Emi, Érika, Fábio, Fernanda, Hermes, Jonas, Júnia, Luciana, Murilo, Hérika, Ana Luisa, Camila, Hérica, Laine, Débora, Fabiano, Juliana, Marcela, Cristiane, Márcia, Natália, Helder, Luana, Renata, Savana.

Aos amigos de laboratório pelos momentos de alegria e de estresse que vivenciamos: Paulinha, Lívia, Ewerton, Juliana Ricco, Mariane, Isis, Flávia, Nancy, Daniela.

Às técnicas do laboratório de Microbiologia, Juliana e Sônia, por toda ajuda, carinho, paciência, amizade e atenção. 
Aos funcionários da Biblioteca, Adriano, Ceres, Eliane, Maria Helena, Maria Inês, Maria José, Marley, Odete e Silvia, por todo carinho e por estarem sempre dispostos a ajudar.

Aos funcionários do Departamento de Clínica Infantil, Soninha, Dulce, Totó, Pedrinho, Odete e Tânia por estarem sempre nos ajudando.

Aos funcionários da Secretaria de Pós-graduação, Alexandre, Sylvia, Rosângela e Flávia, em especial a Mara, por estarem sempre, com toda paciência, nos orientando.

A todos os professores e funcionários desta Faculdade pela atenção.

A todos aqueles que direta e indiretamente tornaram possível este trabalho,

O meu eterno reconhecimento. 


\section{SUMÁRIO}

Lista de abreviaturas, siglas e símbolos................................................. 14

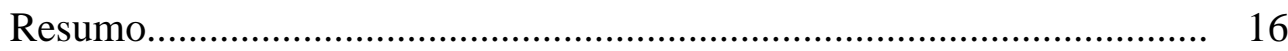

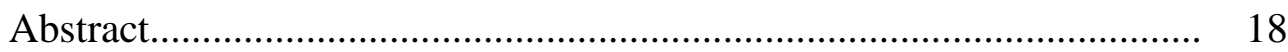

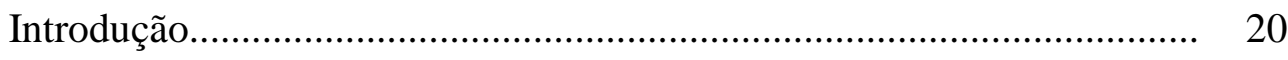

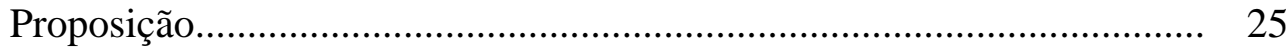

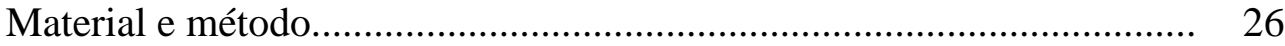

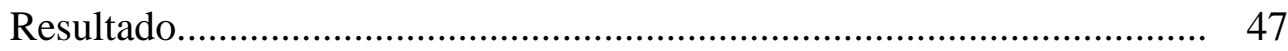

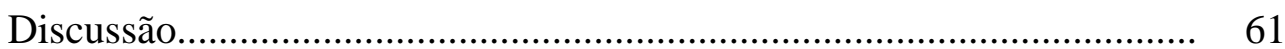

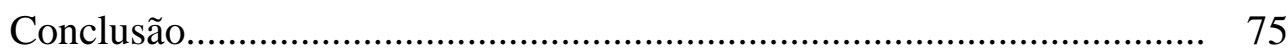

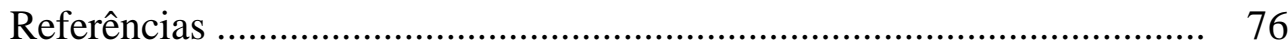

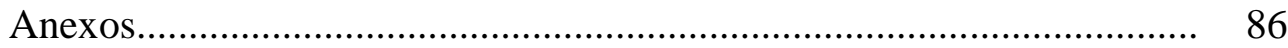




\section{LISTA DE ABREVIATURAS, SIGLAS E SÍMBOLOS}

$\mathrm{C} 1$ - coleta microbiológica inicial

C2 - coleta microbiológica após o preparo biomecânico

C3 - coleta microbiológica após a permanência da medicação intracanal

$\mathrm{Ca}(\mathrm{OH})_{2}$ - hidróxido de cálcio

CAD - comprimento aparente do dente

CLX - gel de digluconato de clorexidina $2 \%$

$\Delta \mathrm{C}$ - diferença entre duas coletas microbiológicas

DNA - ácido desoxirribonucléico

EDTA - ácido etileno diamino tetra-acético

E. faecalis - Enterococcus faecalis

g - gramas

$\mathrm{HCl}$ - ácido clorídrico

$\mathrm{kV}-$ Kilovolts

LPS - lipopolissacarídeo

$\mathrm{M}-$ molar

$\mathrm{mA}$ - miliAmpers

$\mathrm{mL}$ - mililitros

mm - milímetros

$\mathrm{mM}$ - milimolar

MMPs - metaloproteinases

$\mathrm{NaCl}$ - cloreto de sódio 
ng - nanograma

nm - nanometros

nM - nanomolar

p.a. - pró-análise

p - nível de significância estatística

PEG - polietilenoglicol

P. gingivalis - Porphyromonas gingivalis

pH - potencial hidrogeniônico

PCR - "Polymerase Chain Reaction” (reação em cadeia da polimerase)

qRT-PCR - “quantitative Real Time PCR” (reação em cadeia da polimerase em tempo real)

rpm - rotações por minuto

TE - 10mM Tris-HCl, $\mathrm{pH} 8,0+1 \mathrm{mM}$ EDTA, $\mathrm{pH} 8,0$

$\mu \mathrm{M}$ - micromolar

${ }^{\circ} \mathrm{C}$ - Grau Celsius

+ - mais

$\%$ - porcentagem

[ ]-concentração 
Gondim JO. Efeito antibacteriano e sucesso clínico/radiográfico da pasta de hidróxido de cálcio associada à clorexidina como medicação intracanal no tratamento de dentes decíduos humanos com polpa necrótica [Tese de Doutorado]. Araraquara: Faculdade de Odontologia da UNESP; 2010.

\section{RESUMO}

Este trabalho teve como objetivos identificar e quantificar os microrganismos $P$. gingivalis e E. faecalis no interior dos canais radiculares de dentes decíduos humanos com polpa necrótica, avaliar o efeito do preparo biomecânico dos canais radiculares e da pasta de hidróxido de cálcio com clorexidina usada como curativo intracanal sobre esses microrganismos, bem como, avaliar o sucesso clínico e radiográfico da terapia endodôntica. Foram utilizados 32 dentes com polpa necrótica de 28 pacientes entre 3 e 8 anos de idade. Desses dentes, 12 apresentavam-se sem lesão (Grupo I) e 20 com lesão (Grupo II) na região de furca e/ou periapical vista radiograficamente. Após abertura coronária, foi realizada a primeira coleta microbiológica dos canais radiculares, o preparo biomecânico e a segunda coleta microbiológica. Em seguida, metade dos dentes dos grupos I e II recebeu como curativo intracanal a pasta de hidróxido de cálcio em polietilenoglicol $400\left[\mathrm{Ca}(\mathrm{OH})_{2}+\mathrm{PEG}\right]$ (grupo controle), e a outra metade, a pasta de hidróxido de cálcio com clorexidina gel a 2\% $\left[\mathrm{Ca}(\mathrm{OH})_{2}+\mathrm{CLX}\right]$ (grupo experimental). Os dentes foram selados provisoriamente com cimento de ionômero de vidro restaurador. Depois de 30 dias os dentes foram reabertos, o 
curativo intracanal foi removido e, uma terceira coleta microbiológica foi realizada. Todos os dentes tiveram os canais radiculares obturados com pasta de hidróxido de cálcio em polietilenoglicol 400 e foram restaurados. As amostras microbiológicas foram processadas usando PCR (reação em cadeia da polimerase) em tempo real e os resultados foram avaliados pelos testes de Wilcoxon e de Mann-Whitney $(\alpha=0,05)$. Avaliações clínica e radiográfica foram realizadas nos períodos inicial e de 1,3 e 6 meses pós-operatório, sendo os resultados comparados pela aplicação do teste estatístico $Z(\alpha=0,05)$. Não foi verificada diferença significativa entre a microbiota presente nos dentes decíduos sem e com lesão de furca e/ou periapical. O preparo biomecânico foi efetivo na redução dos microrganismos no interior dos canais radiculares de dentes decíduos com polpa necrótica, e, não foi observada diferença estatística na atividade antibacteriana quando as duas pastas usadas como curativo intracanal foram comparadas. Também não houve diferença estatística no sucesso clínico e radiográfico quando os dentes sem e com lesão de furca e/ou periapical foram tratados com $\mathrm{Ca}(\mathrm{OH})_{2}+\mathrm{PEG}$ ou com $\mathrm{Ca}(\mathrm{OH})_{2}+\mathrm{CLX}$. Pode-se concluir que não houve diferença no efeito antibacteriano e na proporção de sucesso clínico e radiográfico entre a pasta de hidróxido de cálcio associada a clorexidina e a pasta de hidróxido de cálcio em polietilenoglicol quando usadas como medicação intracanal no tratamento de dentes decíduos com polpa necrótica.

Palavras-chave: Clorexidina; dente decíduo; endodontia; hidróxido de cálcio; necrose da polpa dentária; reação em cadeia da polimerase. 
Gondim JO. Antibacterial effect and clinical/radiographic success of calcium hydroxide combined with chlorhexidine used as intracanal medication on the treatment of human deciduous teeth with necrotic pulp [Tese de Doutorado]. Araraquara: Faculdade de Odontologia da UNESP; 2010.

\section{ABSTRACT}

This study aimed to identify the microorganisms $P$. gingivalis and E. faecalis in root canals of human deciduous teeth with necrotic pulp, to evaluate the effect of biomechanical preparation of root canals, to evaluate the antibacterial effect of a calcium hydroxide paste prepared with chlorhexidine against these microorganisms, and to evaluate clinical and radiographic success of the endodontic therapy. Thirty two teeth with necrotic pulp of 28 children aged between 3 and 8 years were used. Of these teeth, 12 showed no bone lesions (Group I) and 20 showed radiographic furcation/periapical bone lesions (Group II). After coronal opening and initial microbial root canal sampling, biomechanical preparation and the second microbial sampling were performed. Then, half of the teeth in groups I and II received as intracanal dressing a calcium hydroxide paste in polyethylene glycol $400\left[\mathrm{Ca}(\mathrm{OH})_{2}+\right.$ PEG] (group control), and the other half received calcium hydroxide paste with $2 \%$ chlorhexidine gel $\left[\mathrm{Ca}(\mathrm{OH})_{2}+\mathrm{CHX}\right]$ (experimental group). The teeth were temporarily sealed with 
a glass ionomer filling material. After 30 days the teeth were reopened, the intracanal dressing was removed and a third microbial sampling was performed. All the teeth had the root canals filled with a calcium hydroxide paste in polyethylene glycol 400 and the final restoration was carried. The microbial samples were processed using real time PCR (polymerase chain reaction) analysis and the results were evaluated by Wilcoxon and Mann-Whitney tests $(\alpha=0.05)$. Clinical and radiographic evaluations were performed at 0, 1, 3 and 6 months postoperatively and the results were compared by the $\mathrm{Z}$ statistical test $(\alpha=0.05)$. There was no significant difference between the microbiota present in primary teeth with and without furcation and/or periapical lesions. Biomechanical preparation was effective in reducing microorganisms in root canals of primary teeth with necrotic pulp, and there was no statistical difference in the antibacterial activity when the two intracanal dressings were compared. There was also no statistical difference in clinical and radiographic success when teeth with and without furcation and/or periapical lesions were treated with $\mathrm{Ca}(\mathrm{OH})_{2}+\mathrm{PEG}$ or with $\mathrm{Ca}(\mathrm{OH})_{2}+\mathrm{CHX}$. It could be concluded that there was no difference in the antibacterial effect and in the clinical and radiographic success when the paste of calcium hydroxide combined with chlorhexidine was compared with the paste of calcium hydroxide in polyethylene glycol as intracanal dressing in primary teeth with necrotic pulp

Keywords: Chlorhexidine; tooth, deciduous; endodontics; calcium hydroxide; dental pulp necrosis; polymerase chain reaction. 


\section{INTRODUÇÃO}

Apesar de grandes avanços terem ocorrido na área de prevenção da doença cárie, lesões cariosas extensas que resultam na perda da vitalidade do tecido pulpar ainda são freqüentes na clínica odontopediátrica ${ }^{45}$. E, embora a manutenção dos dentes decíduos até a época da esfoliação natural seja muito importante, atingir este objetivo constitui um grande desafio quando ocorre o envolvimento pulpar.

Estudos têm demonstrado que não existem diferenças estruturais substanciais entre a polpa de dentes decíduos e permanentes humanos ${ }^{14,27}$, porém, para o tratamento endodôntico de dentes decíduos, deve ser considerado o seu ciclo biológico, pois a reabsorção fisiológica determina que a instrumentação dos canais radiculares respeite os limites do bisel de rizólise e que o material obturador seja reabsorvível ${ }^{6}$.

O sucesso do tratamento endodôntico de dentes com polpa necrótica depende de vários fatores e, entre eles, a redução ou eliminação da infecção bacteriana parece ser o mais importante ${ }^{54-55}$. Assim, é importante a identificação dos microrganismos envolvidos no processo. Antes do desenvolvimento de técnicas de cultura estritamente anaeróbias, acreditava-se que a microbiota dos canais radiculares de dentes permanentes com lesão periapical crônica era composta basicamente por microrganismos aeróbios e anaeróbios facultativos $^{48}$. Com o aprimoramento destas técnicas, verificou-se a predominância de microrganismos anaeróbios estritos ${ }^{12,32,64-65}$. Atualmente, 
técnicas mais sensíveis e precisas de biologia molecular estão disponíveis para a identificação e quantificação em tempo real de microrganismos presentes no interior de canais radiculares ${ }^{3,7,18,42}$. Porém, esta tecnologia tem sido pouco empregada na avaliação das infecções endodônticas de dentes decíduos ${ }^{7,39}$.

Mais de 200 espécies de microrganismos foram detectadas em dentes com polpa necrótica. Entretanto, um grupo composto de 15 a 30 espécies tem sido relacionado às infecções endodônticas ${ }^{54-55}$. Desta forma, essas infecções são consideradas de etiologia polimicrobiana, com predomínio de anaeróbios estritos, principalmente Gram negativos, sendo isolados também os anaeróbios facultativos e em menores proporções, os aeróbios ${ }^{7,12,32,51,64-65}$. Estudos longitudinais realizados in vivo têm demonstrado que a proporção de microrganismos anaeróbios estritos aumenta com o tempo, sendo o seu número inversamente proporcional aquele dos anaeróbios facultativos ${ }^{12,65}$.

Métodos de controle químico e mecânico foram desenvolvidos com o objetivo de promover a desinfecção do sistema de canais radiculares. Contudo, estes não garantem, isoladamente, a completa eliminação dos microrganismos, principalmente, em dentes decíduos cujas características da anatomia interna dos canais radiculares dificultam o acesso dos instrumentos endodônticos ${ }^{1,26,53,59,61}$. Assim, as medicações intracanais foram introduzidas para atuarem sobre os microrganismos que resistem ao preparo biomecânico dos canais principais e, principalmente, sobre aqueles que estão situados nos túbulos dentinários, canais secundários e acessórios $6,9,17,26,44,59,61$.

A medicação intracanal deve apresentar propriedades 
antimicrobianas e capacidade de neutralizar os bioprodutos bacterianos com um mínimo de agressão aos tecidos periapicais, além de ser reabsorvida facilmente, quando extravasada para além do ápice radicular, e ser de fácil remoção ${ }^{6}$. Poucos estudos foram realizados com o objetivo de identificar a microbiota específica dos canais radiculares de dentes decíduos com necrose pulpar ${ }^{32,39,51}$, e o efeito da medicação intracanal na eliminação da infecção residual ${ }^{31}$, fatos que dificultam um consenso sobre o medicamento mais eficaz para uso em dentes decíduos ${ }^{4}$.

O hidróxido de cálcio, inicialmente usado sobre polpas vitais expostas com o objetivo de estimular a formação de tecido duro, passou a ser usado como medicamento de escolha para curativo intracanal em dentes com polpa necrótica, principalmente, devido ao seu elevado $\mathrm{pH}$ (aproximadamente 12,5) que lhe confere um excelente poder bactericida ${ }^{26,58,61}$. Considerando que a maioria dos patógenos endodônticos é incapaz de sobreviver em ambiente altamente alcalino $^{27,58,61}$, a ação antimicrobiana deste material está relacionada com a sua capacidade de liberar íons hidroxila em meio aquoso. O hidróxido de cálcio também tem sido amplamente usado na endodontia por ser biocompatível, apresentar ação antiinflamatória e atuar de forma satisfatória no tratamento das reabsorções radiculares patológicas ${ }^{58}$. Além disso, atua sobre o lipopolissacarídeo (LPS), endotoxina presente na parede celular de bactérias Gram negativas, altamente tóxica e potente mediador da inflamação ${ }^{40-41,52}$.

Contudo, estudos mostram que o hidróxido de cálcio é pouco efetivo sobre algumas cepas bacterianas, particularmente sobre o $E$. faecalis $^{11,17,31,44}$. Desta forma, visando aumentar seu poder bactericida, diferentes 
compostos têm sido associados ao hidróxido de cálcio, entre eles, mais recentemente, destaca-se a clorexidina ${ }^{17,19,27,29,31,69}$.

Esta associação do hidróxido de cálcio com a clorexidina foi proposta como medicação intracanal em dentes com necrose pulpar devido ao fato de a clorexidina apresentar ação antimicrobiana imediata considerada de amplo espectro, agindo sobre bactérias Gram positivas, Gram negativas, aeróbios e anaeróbios facultativos e certos fungos ${ }^{10,21,29}$, além de apresentar também, alta substantividade $^{21-22}$. Esta substância também é capaz de inibir metaloproteinases (MMPs), enzimas envolvidas no processo de desenvolvimento de lesões periapicais e reabsorção óssea ${ }^{15,23}$ e apresenta maior capacidade de eliminar o $E$. faecalis do que o hidróxido de cálcio $^{9,17,29,31}$. Entretanto, a literatura relata resultados insatisfatórios para a clorexidina, particularmente, quanto à capacidade de inativar o LPS bacteriano ${ }^{50,66}$. Também foi demonstrado que a clorexidina causa danos às células e quando usada em concentrações não citotóxicas permite significante crescimento bacteriano ${ }^{24,43}$. Apesar disso, a biocompatibilidade desta substância é considerada aceitável quando usada clinicamente ${ }^{29}$.

Pesquisas in vitro ${ }^{9,11,17} \mathrm{e}$ in vivo realizadas em animais $^{38} \mathrm{e}$ em dentes permanentes humanos ${ }^{10,69,26}$ avaliando a atividade antibacteriana da pasta de hidróxido de cálcio associada à clorexidina têm mostrado resultados contraditórios, e, o uso desta associação em dentes decíduos tem sido pouco pesquisado $^{31}$. Em função da escassez de trabalhos em dentes decíduos, é de grande importância a realização de pesquisas que identifiquem e quantifiquem, por meio de técnicas mais sensíveis de biologia molecular, os microrganismos 
envolvidos na infecção endodôntica desses dentes na presença de necrose pulpar com e sem lesão radiográfica na região de furca/periapical, assim como, que avaliem o efeito do preparo biomecânico e da associação do hidróxido de cálcio com a clorexidina como medicação intracanal sobre a microbiota identificada. 


\section{PROPOSIÇÃO}

Avaliar o efeito antibacteriano da pasta de hidróxido de cálcio associada à clorexidina como medicação intracanal sobre os microrganismos E. faecalis e $P$. gingivalis presentes nos canais radiculares de dentes decíduos humanos com polpa necrótica com presença e com ausência de lesão radiográfica na região de furca/periapical, bem como, avaliar o sucesso clínico e radiográfico da terapia endodôntica. 


\section{MATERIAL E METODO}

\section{Delineamento do estudo}

Esta pesquisa consiste em um estudo clínico randomizado duplo cego, no qual estavam cegos os examinadores que realizaram a análise das radiografias e quem processou as amostras para as análises por PCR.

\section{População-amostra}

Foram selecionados para este estudo, 32 dentes de 28 pacientes de ambos os gêneros, com idade entre 3 e 8 anos, que procuraram tratamento no Projeto de Extensão "Atendimento Odontológico de Urgência em Odontopediatria" da Faculdade de Odontologia de Araraquara - UNESP.

\section{Critérios de inclusão}

- Pacientes saudáveis não submetidos à antibioticoterapia sistêmica nos 3 meses que antecederam a pesquisa;

- Pacientes cujos pais/responsáveis concordaram com a sua participação na pesquisa e assinaram o termo de Consentimento Livre e Esclarecido aprovado pelo Comitê de Ética em Pesquisa em Seres Humanos da Faculdade de Odontologia de Araraquara - UNESP (Protocolo 05/07 Anexo 1);

- Pacientes com no mínimo um dente decíduo (anterior ou posterior) com necrose pulpar por cárie em condição de ser restaurado e com pelo menos $2 / 3$ de raiz remanescente; 
- Dentes com necrose pulpar com ausência de lesão periapical ou com lesão periapical que não envolvesse a cripta do germe do dente permanente sucessor;

- Dentes com mobilidade grau 0 (ausente) ou 1 (ligeiramente maior do que o normal), com ausência de bolsa periodontal e que não haviam recebido tratamento endodôntico anterior.

\section{Avaliação das características clínicas e radiográficas dos dentes selecionados}

Os dentes foram avaliados clínica e radiograficamente de acordo com os seguintes critérios:

- $\quad$ sintomatologia dolorosa (presente ou ausente);

- fístula (presente ou ausente);

- edema gengival (presente ou ausente);

- mobilidade dentária patológica (presente ou ausente e grau de mobilidade quando presente);

- radiolucência na região periapical ou de furca (presente ou ausente, e quando presente, tamanho da radiolucência);

- reabsorção radicular patológica (presente ou ausente).

Os dados dessa avaliação foram coletados no exame inicial e nos exames de controle, e anotados em uma ficha de avaliação previamente elaborada (Anexo 2) para posterior comparação. 
A avaliação clínica foi realizada em cadeira odontológica sob luz do refletor, usando o método visual com o auxílio de espelho bucal e empregandose, também, a palpação da área correspondente ao dente afetado.

Todos os cuidados quanto aos riscos relacionados às tomadas radiográficas foram criteriosamente controlados por meio da utilização de avental e protetor de tireóide revestidos por borracha plumbífera, posicionadores de filmes infantis do tipo Han-Shin e filme radiográfico ultra-rápido, possibilitando um baixo tempo de exposição às radiações.

As radiografias foram obtidas de forma padronizada, com distância foco/filme de aproximadamente $20 \mathrm{~cm}$, usando aparelho de raios $\mathrm{X}$ odontológico (Dabi Atante Indústrias Médico-Odontológicas Ltda. - Ribeirão Preto, SP, Brasil), operando com $70 \mathrm{kV}$ e $10 \mathrm{~mA}$, com tempo de exposição de 0,5 segundos. Foram utilizados filmes número 0 ou 2, do tipo Ultraspeed (Eastman Kodak, Rochester, NY, EUA). A revelação das radiografias foi realizada utilizando-se processamento manual pelo método tempo/temperatura em solução reveladora (Kodak, Rochester, NY, EUA), seguida da lavagem intermediária em água corrente por 20 segundos, fixação por 10 minutos, lavagem final em água corrente por 10 minutos e posterior secagem em temperatura ambiente. Após a análise inicial, as radiografias foram arquivadas em cartelas plásticas devidamente identificadas.

Após os exames, clínico e radiográfico, os dentes selecionados foram classificados em dois grupos: Grupo I - dentes com polpa necrótica, sem lesão de furca/periapical visível radiograficamente $(\mathrm{n}=12)$; Grupo II - dentes 
com polpa necrótica e com lesão de furca/periapical visível radiograficamente $(n=20)$.

\section{Tratamento endodôntico e obtenção das amostras microbiológicas}

Os procedimentos foram realizados por um único operador treinado. Inicialmente, foi efetuada a anti-sepsia da cavidade bucal com 5,0 mL de solução de digluconato de clorexidina a 0,12\% (Farmácia Escola - UNESP, Araraquara, SP, Brasil), sob a forma de bochecho por 1 minuto para crianças maiores e, por meio de gaze umedecida em crianças menores de seis anos, sem coordenação motora adequada para realização do bochecho. Após anestesia local usando anestésico com vasoconstritor (Mepivacaína 2\%, DFL Ind. e Comércio Ltda - RJ, Brasil), isolamento absoluto e anti-sepsia do campo operatório com solução de digluconato de clorexidina a $1 \%$ (Farmácia Escola - UNESP, Araraquara, SP, Brasil), toda dentina cariada foi removida com o auxílio de curetas afiadas ou brocas esféricas lisas, em baixa rotação, de tamanho compatível com a cavidade. Foi realizada nova anti-sepsia do campo operatório e da cavidade dentária com solução de digluconato de clorexidina a $1 \%$ a fim de remover detritos e possíveis microrganismos oriundos do tecido cariado e, em seguida, foi completada a abertura coronária com pontas diamantadas esféricas de diâmetro compatível com o tamanho do dente (KG Sorensen - Indústria e Comércio, SP, Brasil) e broca Endo-Z (Les Fils d'August - Maillefer, Suiça) em alta rotação, sob refrigeração ar/água. Em seguida, os canais radiculares foram preenchidos com solução fisiológica para a realização da primeira coleta microbiológica (C1). 
A coleta foi realizada pela introdução consecutiva de quatro cones de papel absorvente esterilizados de calibre 15 (Dentisply Indústria e Comércio Ltda. - RJ, Brasil), em cada canal radicular, por 30 segundos cada, diminuindo 2 mm do comprimento aparente do dente (CAD) medido na radiografia inicial para diagnóstico, levando-se em consideração o ápice ou o limite do bisel de rizólise. Os cones de papel impregnados pelo conteúdo do canal radicular, foram mergulhados em eppendorf contendo 1,0 mL de TE (10 mM Tris-HCl, $\mathrm{pH} \mathrm{8,0+}$ 1 mM EDTA, pH 8,0) e congelados à $-20^{\circ} \mathrm{C}$ até a extração do DNA para analise microbiológica por meio de reação em cadeia da polimerase em tempo real (qRTPCR). No caso de dentes multirradiculares, foram introduzidos quatro cones de papel absorvente no interior de cada canal radicular, os quais foram armazenados em um único eppendorf, sendo posteriormente realizados cálculos matemáticos, de forma que as coletas dos diferentes canais radiculares do mesmo dente correspondessem à amostra microbiológica da unidade dentária.

Após a coleta, foi realizada a neutralização imediata e progressiva do conteúdo séptico-tóxico, no sentido coroa-ápice sem pressão, por meio da limpeza com instrumentos manuais dos terços cervical e médio do canal radicular, anteriormente à intervenção no terço apical. Foram utilizadas limas tipo K (Dentsply - Maillefer, Suiça), inicialmente compatíveis com o terço cervical do canal e, a seguir, com calibres menores, até atingir o terço apical. A penetração das limas foi associada a abundante irrigação/aspiração com solução de hipoclorito de sódio a $1 \%$ em um volume de $1,8 \mathrm{~mL}$ a cada troca de instrumento. A tomada radiográfica para odontometria de cada conduto radicular foi realizada 
diminuindo-se 1,5 a $2,0 \mathrm{~mm}$ do $\mathrm{CAD}$ medido na radiografia inicial para diagnóstico, levando-se em consideração o ápice ou o limite do bisel de rizólise, nos casos de necrose pulpar sem lesão de furca/periapical (Grupo I) e diminuindose 1,0 mm do CAD nos casos de necrose pulpar com lesão de furca/periapical (Grupo II).

Nos dentes do Grupo II, foi realizada a limpeza do 1,0 $\mathrm{mm}$ apical por meio do desbridamento foraminal utilizando o primeiro instrumento a se prender às paredes dentinárias no $\mathrm{CAD}$ associado com o uso da solução irrigadora. Após este passo, o instrumento foi recuado $1 \mathrm{~mm}$ e iniciou-se o preparo biomecânico, por meio da limagem dos canais radiculares com limas tipo K $\quad\left(1^{\mathrm{a}}\right.$ e $2^{\mathrm{a}}$ Séries - Dentsply - Maillefer, Suiça $)$ intercaladas por irrigação/aspiração/inundação com solução de hipoclorito de sódio a 1\%, em um volume de $1,8 \mathrm{~mL}$ a cada troca de instrumento. $\mathrm{O}$ procedimento de instrumentação envolveu movimentos de limagem utilizando, em média, três limas a partir do primeiro instrumento introduzido no canal, intercaladas com irrigação com solução de hipoclorito de sódio a 1\%. Finalizada a instrumentação dos canais, foi realizada irrigação/aspiração e secagem dos canais radiculares com cones de papel absorvente, e estes foram preenchidos com EDTA (solução de ácido etileno diamino tetra-acético 16\%, pH 7,4 - Biodinâmica, Pr, Brasil), que permaneceu por 3 minutos no interior dos canais sob constante agitação com lima tipo K. Esta solução foi removida e neutralizada com 1,8 mL de solução de hipoclorito de sódio a $1 \%$, seguido da irrigação com $1,8 \mathrm{~mL}$ de solução fisiológica. 
A segunda coleta microbiológica $(\mathrm{C} 2)$ foi realizada logo após o término do preparo biomecânico dos canais radiculares, como já descrito para a primeira coleta.

Após o término desta etapa, os canais radiculares foram novamente irrigados, aspirados e secos com o auxílio de cones de papel absorvente esterilizados e a medicação selecionada por meio de sorteio foi colocada em seu interior. Assim sendo:

metade da amostra de cada grupo (GI - $n=6$ e GII - $n=10)$ recebeu como medicação intracanal uma pasta de hidróxido de cálcio p.a. (Merck, KGaA Frankfurter Strasse, Darmstadt, Alemanha) com polietilenoglicol 400 (PEG 400 - Labsynth - Produtos para Laboratório LTDA, SP, Brasil), na proporção de 1:1 (g/mL), (Grupo controle).

a outra metade da amostra de cada grupo (GI - n=6 e GII - n=10) recebeu como medicação intracanal uma pasta de hidróxido de cálcio p.a. (Merck, KGaA Frankfurter Strasse, Darmstadt, Alemanha)com gel de digluconato de clorexidina a 2\% (CLX - Farmácia Escola -UNESP, SP, Brasil) também na proporção de 1:1 (g/mL) (Grupo experimental).

As pastas foram manipuladas sob condições assépticas com o auxílio de placa de vidro e espátula no 24 (Duflex - S.S.White Artigos Dentários Ltda., RJ, Brasil) e foram levadas com o auxílio de broca lentulo (Dentsply Maillefer, Suiça), preenchendo todo o canal instrumentado. Em seguida, a câmara coronária foi limpa, uma mecha de algodão esterilizada foi colocada em contato com as entradas dos canais radiculares e o dente foi restaurado provisoriamente 
com cimento de ionômero de vidro (Ketac Fill - 3M ESPE, Dentsply Indústria e Comércio Ltda., RJ, Brasil). Para a visualização do adequado preenchimento do canal radicular com a medicação foi realizada tomada radiográfica conforme descrito anteriormente. A seqüência clínica de tratamento e realização da $1^{\mathrm{a}}$ e $2^{\mathrm{a}}$ coletas microbiológicas está apresentada a seguir na Figura 1. 

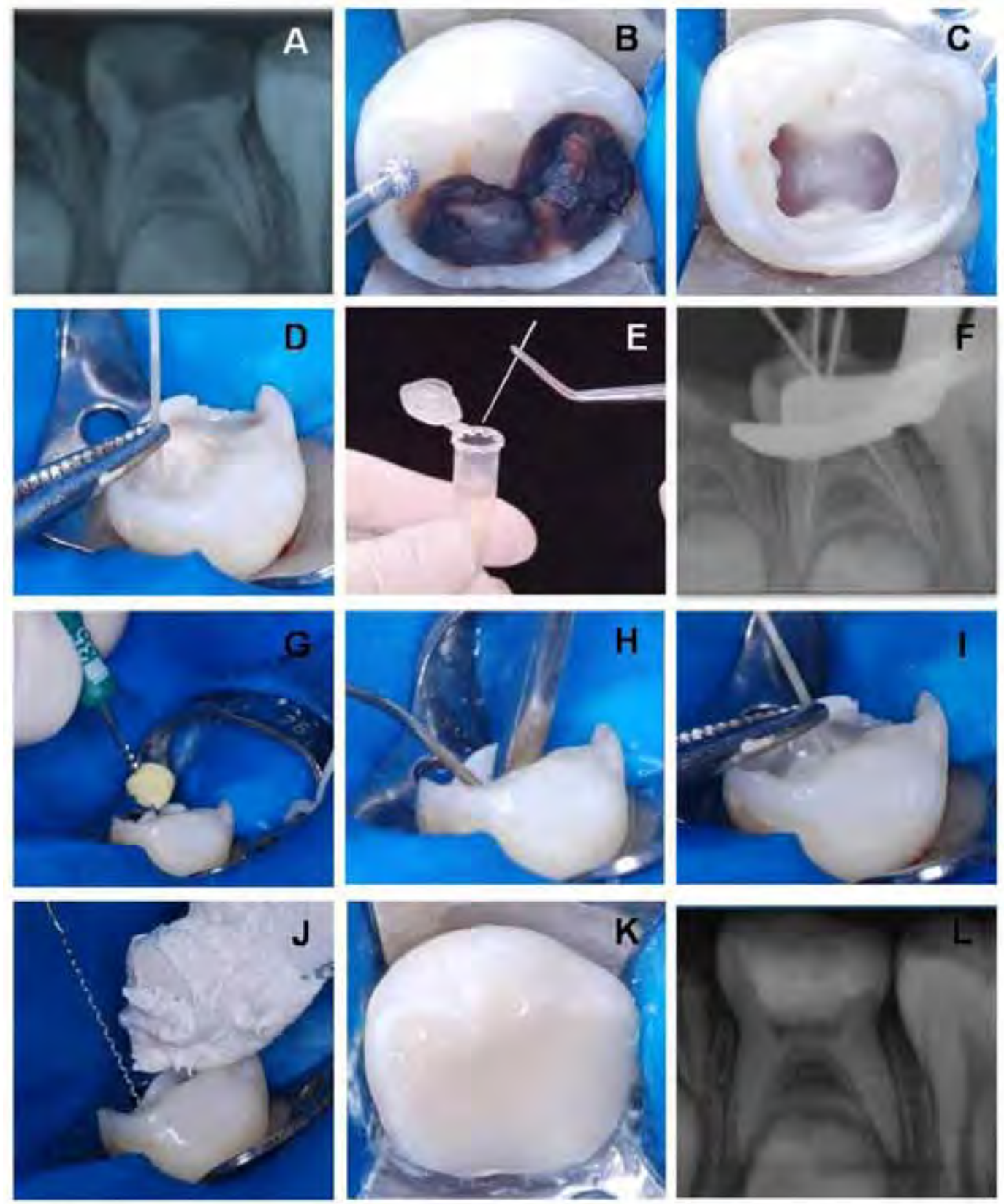

FIGURA 1 - Seqüência clínica de tratamento e realização da $1^{\mathrm{a}}$ e $2^{\mathrm{a}}$ coletas microbiológicas. (A) Aspecto radiográfico do dente 75 sem lesão de furca/periapical ; (B) Isolamento do campo operatório com dique de borracha; (C) Abertura coronária; (D) Primeira coleta microbiológica; (E) Armazenamento dos cones em eppendorf conts cgcendo TE; (F) Radiografia para odontometria; (G) Preparo biomecânico; (H) Irrigação/aspiração; (I) Segunda coleta microbiológica; (J) Inserção da medicação intracanal com auxílio de broca lentulo; (K) Selamento coronário provisório; (L) Radiografia para avaliação do preenchimento do canal radicular com a medicação. 
A distribuição dos grupos experimentais está descrita na Tabela 1.

Tabela 1 - Distribuição da amostra de acordo com o tipo de dente decíduo, a presença ou não de lesão na região de furca/periapical e o tipo de medicação intracanal

\begin{tabular}{ccccc}
\hline Grupos & Tipo de dente & \multicolumn{2}{c}{ Medicação intracanal } & Total \\
\hline $\begin{array}{c}\mathrm{Ca}(\mathrm{OH})_{2}+\mathrm{PEG} \\
\mathrm{I}\end{array}$ & incisivos e caninos & 3 & 3 & 6 \\
$\begin{array}{c}\text { (Polpa necrosada } \\
\text { sem }\end{array}$ & molares & 3 & 3 & 6 \\
$\begin{array}{c}\text { lesão de } \\
\text { furca/periapical) }\end{array}$ & incisivos e caninos & 6 & 6 & 12 \\
\hline $\begin{array}{c}\text { II } \\
\text { (Polpa necrosada } \\
\text { com lesão de } \\
\text { furca/periapical) }\end{array}$ & molares & 4 & 4 & 8 \\
\hline \begin{tabular}{c} 
Total de Dentes \\
\hline
\end{tabular} & & 16 & 16 & 32 \\
\hline
\end{tabular}

A medicação foi mantida no interior dos canais radiculares por um período de 30 dias $^{30}$.

Decorrido esse período, os dentes receberam isolamento absoluto, foram reabertos e a medicação intracanal foi removida com o auxílio de irrigação/aspiração com soro fisiológico e passagem do último instrumento endodôntico utilizado no preparo biomecânico. O canal radicular foi seco com o auxílio de cones de papel absorvente esterilizados, uma mecha de algodão esterilizada foi colocada na câmara coronária, e o dente foi novamente selado provisoriamente com cimento de ionômero de vidro (Ketac Fill - 3M ESPE, Dentisply Indústria e Comércio Ltda., RJ, Brasil). A sequiência clínica para remoção da medicação dos canais radiculares está ilustrada a seguir na Figura 2. 

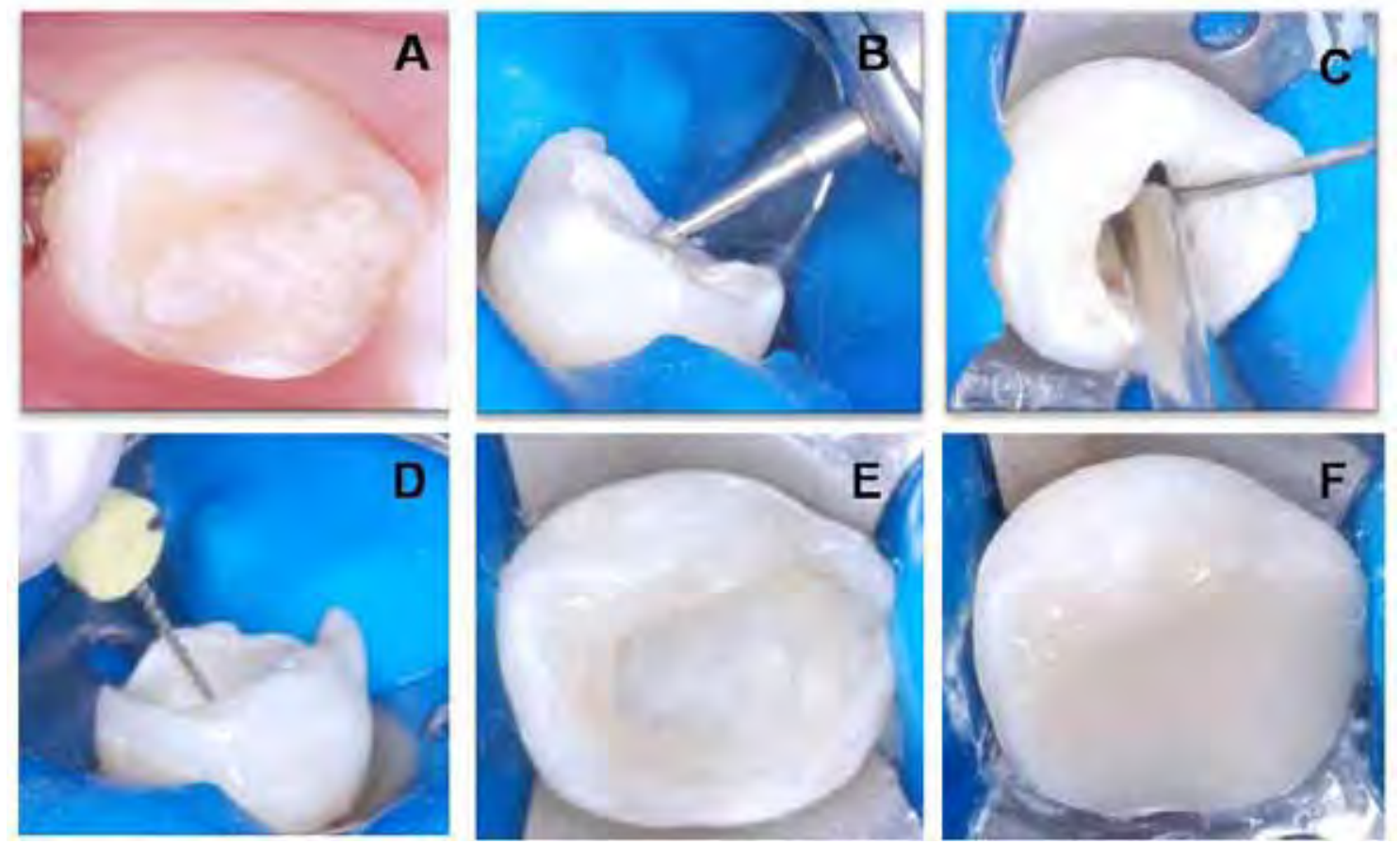

FIGURA 2 - Seqüência clínica da remoção da medicação dos canais radiculares.

(A) Aspecto clínico 30 dias após inserção da medicação intracanal; (B)

Isolamento do campo operatório com dique de borracha e remoção da restauração provisória; (C, D) Remoção da medicação intracanal com o auxílio de irrigação com soro fisiológico e utilização do último instrumento endodôntico usado no preparo biomecânico; (E, F) Colocação de uma mecha de algodão esterilizada na entrada dos canais e selamento provisório da cavidade.

O dente permaneceu nessa condição por um período de 72 horas $^{13}$, tempo necessário para que caso existissem microrganismos residuais no interior dos túbulos dentinários, canais secundários e acessórios, estes migrassem para a luz do canal principal e fossem identificados na terceira coleta microbiológica (C3). Decorrido este período, após isolamento absoluto e anti-sepsia do campo operatório, a restauração provisória foi removida, o canal radicular foi inundado 
com solução fisiológica e a terceira e última coleta microbiológica (C3) foi efetuada como descrito previamente. Essa coleta teve como objetivo avaliar o efeito da medicação intracanal sobre os microrganismos inicialmente identificados.

Em seguida, o canal radicular foi submetido à abundante irrigação/aspiração com solução de hipoclorito de sódio a $1 \%$ em um volume de 1,8 mL, secagem com cones de papel absorvente esterilizadas e foi preenchido com solução de EDTA, por 3 minutos, sob agitação com lima, para uma maior limpeza, e, consequentemente, um contato mais íntimo do material obturador com as paredes dentinárias. Essa solução foi removida e neutralizada pela irrigação com solução de hipoclorito de sódio a $1 \%$, seguido de solução fisiológica, aspiração e secagem do canal radicular com auxílio de cones de papel absorvente. A obturação do canal foi realizada com pasta a base de hidróxido de cálcio (CALEN - S.S.White Artigos Dentários Ltda., RJ, Brasil) espessada com pó de óxido de zinco (S.S.White Artigos Dentários Ltda., RJ, Brasil) ${ }^{49}$. A entrada do canal radicular e o assoalho da câmara pulpar, em dentes multiradiculares, foram protegidos com uma camada de cimento de hidróxido de cálcio (Dycal Dentisply Indústria e Comércio Ltda., RJ, Brasil), seguido da confecção de uma base cavitária com cimento de ionômero de vidro (Ketac Fill - 3M ESPE, Dentisply Indústria e Comércio Ltda. - RJ, Brasil) e restauração definitiva do dente com resina composta (Z100 - 3M ESPE, St. Paul, MN, EUA) em dentes anteriores e com amálgama (Velvalloy - S.S.White Artigos Dentários Ltda., RJ, Brasil) em dentes posteriores. Finalizada a restauração, foi realizada uma tomada 
radiográfica periapical para certificação do adequado preenchimento dos canais radiculares. A seqüência clínica para realização da $3^{\mathrm{a}}$ coleta microbiológica e obturação definitiva dos canais radiculares está apresentada na Figura 3.
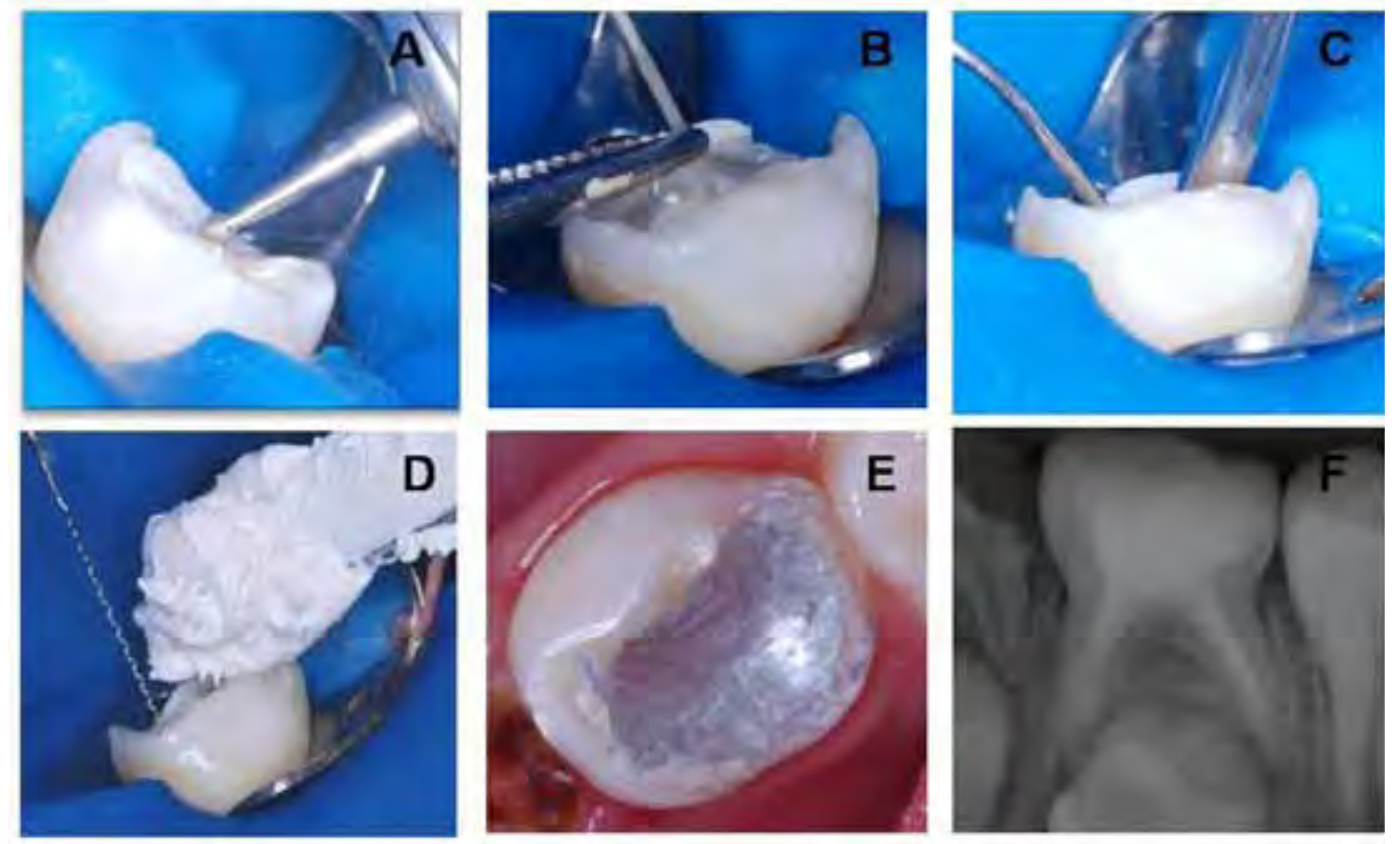

FIGURA 3 - Sequiência clínica da realização da $3^{\text {a }}$ coleta microbiológica e obturação definitiva dos canais radiculares. (A) Remoção da restauração provisória com campo operatório isolado; (B) Terceira coleta microbiológica; (C) Irrigação/aspiração dos canais radiculares; (D) Obturação dos canais radiculares com o auxílio de broca lentulo; (E) Restauração definitiva do dente; (F) Radiografia final evidenciando a obturação adequada dos canais radiculares.

\section{Processamento e análise das amostras microbiológicas}

A análise das amostras microbiológicas obtidas foi feita por meio da qRT-PCR (quantitative real time PCR). Esse teste teve como objetivo detectar, quantitativamente, as bactérias $P$. gingivalis e E. faecalis. Para a realização do 
qRT-PCR foi necessária a extração do DNA bacteriano total das amostras coletadas em $\mathrm{C} 1, \mathrm{C} 2$ e C3.

- Extração do DNA bacteriano. Os eppendorfs foram descongelados e agitados em vortex (Phoenix AP 56, Araraquara, SP, Brasil) por 1 minuto. Foi retirada uma alíquota de 100 microlitros $(\mu \mathrm{L})$ de cada amostra e estas foram mantidas em banho seco (Thermomixer Comfort, Eppendorf Ag 22331, Hamburg, Alemanha) a $97^{\circ} \mathrm{C}$ por 10 minutos. Cem microlitros de TE $(10 \mathrm{mM}$ Tris- $\mathrm{HCl}, \mathrm{pH} 8,0+1 \mathrm{mM}$ EDTA, pH 8,0) foram adicionados aos eppendorfs e, em seguida, foram acrescentados $200 \mu \mathrm{L}$ de Fenol:Clorofórmio:Álcool isoamílico (25:24:1). As amostras foram homogeneizadas em vortex duas vezes por 1 minuto cada e centrifugadas por 5 minutos a $14.000 \mathrm{rpm}$. O sobrenadante foi transferido para outro eppendorf e esta etapa foi repetida por mais duas vezes. Os eppendorfs foram acrescidos de $25 \mu \mathrm{L}$ de $\mathrm{NaCl} 5 \mathrm{M}$, em seguida foram preenchidos com etanol absoluto gelado e homogeneizados manualmente por 20 vezes suavemente. Os eppendorfs foram levados ao freezer $-20^{\circ} \mathrm{C}$ por 20 minutos. Após este período, as amostras foram, novamente, centrifugadas por 10 minutos a $14.000 \mathrm{rpm}$. O sobrenadante foi retirado e descartado, deixando somente o pellet correspondente ao DNA. Os pellets foram lavados 2 vezes com $1 \mathrm{~mL}$ de etanol $75 \%$ gelado, homogeneizados manualmente por 20 vezes suavemente. O etanol foi descartado e os eppendorfs foram deixados à temperatura ambiente $\left(24 \pm 1^{\circ} \mathrm{C}\right)$ até a sua completa evaporação. Após seco, o precipitado foi ressuspendido em $70 \mu \mathrm{L}$ de TE. A concentração de DNA foi determinada por espectrofotometria de luz UV 
(Biomate 3 - Thermo Electron Corporation) a $260 \mathrm{~nm}$, e a relação entre as absorbâncias a 260/280 nm foi analisada. Como parâmetro de qualidade, foi considerada como adequada entre 1,8-2,0.

- Desenho dos primers. As seqüências dos primers específicos para P. gingivalis e E. faecalis foram obtidos a partir da literatura ${ }^{25,47}$ (Tabela 2) e sintetizados pela Invitrogen (Invitrogen Tech-Line ${ }^{\mathrm{SM}}$ ). Em seguida, esses primers foram avaliados quanto a sua especificidade pela verificação da curva de dissociação (curva de Melting), onde é possível observar apenas um pico de dissociação para cada par de oligonucleotídeos utilizados. A presença de apenas um pico comprova que apenas um fragmento está sendo amplificado independentemente da concentração de oligonucleotídeos.

Tabela 2 - Seqüência de primers específicos para os microrganismos avaliados no presente estudo

\begin{tabular}{|c|c|c|c|}
\hline Microrcanismo & \multicolumn{3}{|c|}{ PRIMER } \\
\hline P. gingivalis ${ }^{*}$ & 5' CTTGACTTCAGTGGCGGCAG & $3^{\prime}$ & 5' AGGGAAGACGGTTTTCACCA 3' \\
\hline E. faecalis $^{* *}$ & 5' CCGAGTGCTTGCACTCAATTGG & $3^{\prime}$ & 5' CTCTTATGCCATGCGGCATAAAC $3^{\prime}$ \\
\hline
\end{tabular}

- Otimização e validação dos primers. A utilização do SYBR Green PCR (Applied Biosystems, Califórnia, EUA) exige a obtenção de produtos específicos de PCR. Em função disso, a eficácia das reações para primers foi otimizada antes 
do início das reações propriamente ditas. Para isso, concentrações variando de $0,25 \mu \mathrm{M}$ a $0,7 \mu \mathrm{M}$ de cada primer foram utilizadas para determinar em quais condições a reação teria a melhor eficiência. A eficiência de amplificação (Ef.) dos pares de oligonucleotídeos utilizados foi determinada pela fórmula $\left[\text { Ef. }=10^{(-1 / \text { slope })}-1\right]^{37}$.

- PCR em tempo real. As amostras de todos os casos foram avaliadas quanto à presença de bactérias por meio do ensaio de qRT-PCR usando o equipamento 7500 Real Time PCR System (Applied Biosystems ${ }^{\circledR}$, California, EUA). Foi utilizado o sistema baseado no fluorocromo SYBR, fazendo uso do kit Power SYBR Green PCR Master Mix (Applied Biosystems ${ }^{\circledR}$, California, EUA), de acordo com as condições recomendadas pelo fabricante.

Para realização da curva padrão, após extração do DNA das cepas puras, obteve-se uma concentração inicial $0,5-0,6 \mu \mathrm{g} / \mu \mathrm{L}$ de cada DNA bacteriano. Em seguida, realizou-se oito diluições seriadas e após otimização foram selecionadas quatro diluições por placa $\left(10^{4}-10^{7}\right)$ para confecção da curva padrão. Esta foi utilizada para converter os escores de Ct (Cycle Treshold) obtidos com as amostras de fluido em números de concentração de DNA.

As reações foram realizadas em triplicata, em placas específicascontendo 96 poços (MicroAmp Applied Biosystems ${ }^{\circledR}$, California, EUA), seladas com adesivos ópticos (Applied Biosystems ${ }^{\circledR}$, Califórnia, EUA). Cada placa continha as coletas 1,2 e 3 referentes a 6 dentes e quatro amostras com diferentes concentrações conhecidas de DNA das cepas puras $(0,01 \mu \mathrm{g}$, 
$0,1 \mu \mathrm{g}, 1 \mu \mathrm{g}$ e $10 \mu \mathrm{g})$ que serviu para confecção da curva padrão. Além disso, a placa continha um poço com a mistura para reação de PCR, entretanto, sem a presença de DNA para cada uma das amostras estudadas, inclusive para curva padrão, como controle negativo. Cada reação continha um volume total de $20 \mu \mathrm{L}$, sendo $10 \mu \mathrm{L}$ de Sybr Green, $1,0-2,8 \mu \mathrm{L}$ de primers (forward e reverse), $1 \mu \mathrm{L}$ de DNA. O volume final foi ajustado com água estéril livre de DNAse e RNAse. A termociclagem utilizada foi de $95^{\circ} \mathrm{C}$ por 10 minutos, 40 ciclos a $95^{\circ} \mathrm{C}$ por 15 segundos e $60^{\circ} \mathrm{C}$ por um minuto. Após a reação de PCR foi realizada a curva de dissociação com temperatura entre $60^{\circ} \mathrm{C}$ e $95^{\circ} \mathrm{C}$. Os dados foram analisados utilizando o programa Step One ${ }^{\mathrm{TM}}$ (Appied Biosystems ${ }^{\circledR}$, Califórnia, EUA).

\section{Avaliação clínica e radiográfica}

No exame inicial e nos exames de controle realizados nos períodos de 1, 3 e 6 meses após o tratamento endodôntico, os seguintes dados clínicos foram registrados: história de dor espontânea indicativa de periodontite apical, presença de fístula ou abcesso, presença de edema gengival, e mobilidade patológica. Radiograficamente, foram avaliados sinais de radiolucência na região de furca/periapical e de reabsorção radicular patológica (Anexo 2).

Os dados clínicos coletados no exame inicial e no controle de 6 meses de pós-operatório e a comparação da radiografia inicial para diagnóstico com a radiografia realizada no exame de controle de 6 meses foram a base para avaliação do sucesso ou insucesso da terapêutica endodôntica. As radiografias foram analisadas por dois profissionais experientes, com o auxílio de uma lente 
com aumento de 2X (VRX - Fabinject, Taubaté, SP, Brasil) e negatoscópio. Estes profissionais não tinham nenhuma informação com relação ao grupo de tratamento ao qual cada dente pertencia e, em caso de dúvidas durante a avaliação, foi estabelecido um consenso entre os examinadores.

Os critérios avaliados para considerar sucesso ou falha na terapia endodôntica instituída foram os seguintes:

1. Reparo completo (= sucesso)

- Clinicamente: ausência de sinais e sintomas, e,

- Radiograficamente: ausência de reabsorção radicular patológica, largura do espaço do ligamento periodontal normal, ausência de desenvolvimento de lesão na região de furca/periapical nos casos de ausência de lesão observada na radiografia inicial para diagnóstico e regressão total da lesão quando presente no inicio do tratamento.

2. Reparo incompleto (= sucesso)

- Clinicamente: ausência de sinais e sintomas, e,

- Radiograficamente: ausência de reabsorção radicular patológica e redução em tamanho da lesão na região de furca/periapical.

3. Ausência de reparo (= insucesso)

- Clinicamente: sinais e sintomas indicativos de periodontite apical em fase aguda, e/ou,

- Radiograficamente: presença de reabsorção radicular patológica, lesão na região de furca/periapical de tamanho inalterado durante 
o período de acompanhamento, aumento ou desenvolvimento de nova lesão radiográfica.

\section{Análise dos resultados}

\section{Dados obtidos por PCR em Tempo Real}

Análise 1: Comparação da concentração de DNA bacteriano em canais de dentes decíduos com necrose pulpar com presença e com ausência de lesão visível $\underline{\text { radiograficamente na região de furca/periapical. }}$

Inicialmente foi avaliada a distribuição dos dados obtidos a partir da coleta inicial (C1), empregando-se o teste de Shapiro-Wilks $(\mathrm{n}=32)$. Em seguida, como não foram obedecidos os critérios de normalidade, a concentração de DNA da bactéria $P$. gingivalis para as condições independentes: presença e ausência de lesão visível radiograficamente na região de furca/periapical de dentes decíduos com necrose pulpar foi comparada utilizando o teste não paramétrico de Mann-Whitney.

Para o E. faecalis foi feita apenas análise descritiva, devido ao pequeno número de amostras que continham este microrganismo.

Análise 2: Avaliação da eficácia do preparo biomecânico na neutralização dos microrganismos identificados nos canais radiculares de dentes decíduos com 
polpa necrótica com presença e com ausência de lesão visível radiograficamente na região de furca/periapical.

A concentração de DNA de $P$. gingivalis foi comparada entre as coletas 1 e 2 ( $\mathrm{C} 1$ e C2), separadamente, para as condições: presença e ausência de lesão visível radiograficamente na região de furca/periapical de dentes decíduos com necrose pulpar, usando o teste de Wilcoxon.

Para comparar a eficácia do preparo biomecânico em dentes com e sem lesão visível radiograficamente foi utilizada a diferença entre $\mathrm{C} 1$ e $\mathrm{C} 2\left(\Delta_{\mathrm{C}}\right)$, e aplicado o teste de Mann-Whitney.

Análise 3: Avaliação do efeito da medicação intracanal sobre a microbiota presente nos canais radiculares de dentes decíduos com polpa necrótica com presença e com ausência de lesão visível radiograficamente na região de furca/periapical.

As condições: dentes decíduos com necrose pulpar sem lesão e dentes decíduos com necrose pulpar e lesão visível radiograficamente na região de furca/periapical foram avaliadas separadamente. A concentração de DNA bacteriano foi comparada entre as coletas 2 e 3 (C2 e C3) para as condições: medicação intracanal com hidróxido de cálcio + PEG e medicação intracanal com hidróxido de cálcio + CLX, usando o teste de Wilcoxon. 
Para comparar a eficácia da medicação intracanal (hidróxido de cálcio + PEG e hidróxido de cálcio + CLX) foi utilizada a diferença entre C2 e C3 $\left(\Delta_{\mathrm{C}}\right)$ e aplicado teste de Mann-Whitney.

\section{Avaliação Clínica e Radiográfica}

Os dados relativos às análises clínica e radiográfica dos dentes decíduos com necrose pulpar foram avaliados, nos períodos inicial e aos 6 meses, para as condições: presença e ausência de lesão visível radiograficamente na região de furca/periapical, bem como, para as condições: tratamento com hidróxido de cálcio + PEG e tratamento com hidróxido de cálcio + CLX, utilizando o Teste Z para comparação de proporções.

Todos os testes estatísticos foram avaliados considerando o nível de significância de $5 \%(\alpha=0,05)$. 


\section{RESULTADOS}

\section{Análise por PCR em Tempo Real}

Na coleta microbiológica inicial (C1), dos 32 dentes da amostra, a P. gingivalis foi identificada em 28 casos e o E. faecalis em apenas três. Em dois dentes foram identificados concomitantemente a P. gingivalis e o E. faecalis, enquanto que em três dentes não foi identificado nenhum destes microrganismos.

Em relação ao E. faecalis, um dente apresentava lesão na região de furca/periapical visível radiograficamente e os outros dois não apresentavam lesão. Assim, devido ao baixo número de amostras que continham este microrganismo, foi realizada apenas uma avaliação descritiva dos dados.

Nos dois dentes com polpa necrótica sem lesão, nos quais este microrganismo foi identificado em $\mathrm{C} 1$, não foi observada amplificação de DNA em C2 e C3. Enquanto que no outro dente, o qual apresentava lesão visível radiograficamente, o preparo biomecânico não foi efetivo em eliminar completamente este microrganismo do interior dos canais radiculares. Este dente apresentou agudização do processo infeccioso e níveis de DNA bacteriano, em C3, semelhantes aqueles detectados inicialmente.

Na tabela 3 pode-se verificar a distribuição da amostra, de acordo com os seguintes dados: presença ou não de lesão, medicação intracanal, dente, concentração de DNA de $P$. gingivalis (ng x $10^{-6}$ ), de acordo com as diferentes coletas $(\mathrm{C} 1, \mathrm{C} 2, \mathrm{C} 3)$. 
Tabela 3 - Distribuição da amostra de acordo com presença ou não de lesão, medicação intracanal, dente e concentração de DNA de P.gingivalis (ng $\times 10^{-6}$ ) de acordo com as diferentes coletas microbiológicas

\begin{tabular}{|c|c|c|c|c|c|}
\hline \multirow[t]{2}{*}{ Grupo } & \multirow{2}{*}{$\begin{array}{l}\text { Medicação } \\
\text { intracanal }\end{array}$} & \multirow[t]{2}{*}{ Dente } & \multicolumn{3}{|c|}{$\begin{array}{l}\text { [ ] de DNA de P. gingivalis } \\
\left(\text { ng } \times 10^{-6}\right)\end{array}$} \\
\hline & & & Coleta 1 & Coleta 2 & Coleta 3 \\
\hline \multirow{12}{*}{$\begin{array}{c}\text { I } \\
\text { (Polpa necrótica } \\
\text { sem lesão de } \\
\text { furca/periapical) }\end{array}$} & \multirow{6}{*}{$\mathrm{Ca}(\mathrm{OH})_{2}+\mathrm{PEG}$} & 51 & 0,22 & 0 & 0 \\
\hline & & 75 & 0 & 0 & 0 \\
\hline & & 75 & 3,87 & 0,27 & 4,42 \\
\hline & & 52 & 0 & 0 & 0,08 \\
\hline & & 62 & 23,40 & 0,35 & 0,01 \\
\hline & & 75 & 0,27 & 0 & 0,02 \\
\hline & \multirow{6}{*}{$\mathrm{Ca}(\mathrm{OH})_{2}+\mathrm{CLX}$} & 53 & 4,73 & 0,18 & 0,23 \\
\hline & & 55 & 8,28 & 0,10 & 0,70 \\
\hline & & 75 & 29,00 & 38,23 & 0 \\
\hline & & 63 & 10,00 & 0 & 0 \\
\hline & & 85 & 2,43 & 0 & 0 \\
\hline & & 61 & 15,75 & 2,16 & 7,82 \\
\hline \multirow[t]{9}{*}{$\mathrm{n}=20$} & & & & & \\
\hline & \multirow{10}{*}{$\mathrm{Ca}(\mathrm{OH})_{2}+\mathrm{PEG}$} & 62 & 105,55 & 0,05 & 0 \\
\hline & & 51 & 6,41 & 2,17 & 0,41 \\
\hline & & 85 & 102,17 & 45,30 & 103,67 \\
\hline & & 85 & 1,19 & 0 & 0 \\
\hline & & 74 & 0 & 0 & 0,01 \\
\hline & & 61 & 111,20 & 0,74 & 4,85 \\
\hline & & 51 & 0,65 & 0,03 & 0,29 \\
\hline & & 75 & 1,55 & 0,02 & 4,72 \\
\hline II & & 52 & 0,48 & 0 & 0 \\
\hline \multirow{10}{*}{$\begin{array}{l}\text { (Polpa necrótica } \\
\text { com lesão de } \\
\text { furca/periapical) }\end{array}$} & & 51 & 3,84 & 0,73 & 5,96 \\
\hline & \multirow{10}{*}{$\mathrm{Ca}(\mathrm{OH})_{2}+\mathrm{CLX}$} & 61 & 3,02 & 0,08 & 0,08 \\
\hline & & 61 & 3,39 & 0 & 0,57 \\
\hline & & 61 & 6,26 & 0 & 20,75 \\
\hline & & 84 & 99,05 & 2,16 & 7,82 \\
\hline & & 75 & 12,50 & 2,14 & 8,46 \\
\hline & & 75 & 0 & 0 & 0 \\
\hline & & 85 & 0,65 & 0 & 2,54 \\
\hline & & 61 & 31,80 & 2,45 & 14,90 \\
\hline & & 61 & 13,13 & 3,97 & 4,30 \\
\hline $\mathrm{n}=20$ & & 51 & 0,34 & 0 & 0 \\
\hline
\end{tabular}


A P.gingivalis foi identificada em 10 dos 12 dentes que não apresentavam lesão visível radiograficamente e em 18 dos 20 dentes que apresentavam lesão, não sendo observada diferença estatisticamente significante ( $p>0,05)$ na concentração de DNA da P.gingivalis em relação a presença ou não de lesão na região de furca/periapical (Tabela 4).

Tabela 4 - Comparação da concentração de DNA (mediana, P25 e P75) de $P$. gingivalis em canais de dentes decíduos com necrose pulpar com presença ou ausência de lesão visível radiograficamente na região de furca/periapical na coleta inicial

\begin{tabular}{cl}
\hline Lesão & $\begin{array}{l}\text { P. gingivalis - Coleta } 1 \\
{\left[\text { ] de DNA }\left(\mathrm{ng} \times 10^{-6}\right)\right.}\end{array}$ \\
\hline Ausente $(\mathrm{n}=12)$ & $4,30(0,23-14,31) \mathrm{a}$ \\
Presente $(\mathrm{n}=20)$ & $3,61(0,65-27,30) \mathrm{a}$ \\
\hline
\end{tabular}

Letras iguais denotam ausência de diferença estatística (Mann-Whitney, p>0,05).

A Tabela 5 mostra os resultados relativos a eficácia do preparo biomecânico na neutralização do microrganismo P.gingivalis identificado na coleta inicial $(\mathrm{C} 1)$. Pode-se verificar que o preparo biomecânico promoveu uma redução significativa da concentração do DNA bacteriano, sendo observada uma maior concentração de DNA em $\mathrm{C} 1$ quando comparado a C2, independente da presença ou não de lesão de furca/periapical (Wilcoxon, $\mathrm{p}<0,05$ ). Calculando-se a diferença dos valores obtidos nas duas coletas $\left(\Delta_{C}=\right.$ C1-C2), não foi observada diferença estatística na redução da concentração de DNA dessa bactéria 
determinada pelo preparo biomecânico, quando foram comparados dentes com lesão com aqueles sem lesão de furca/periapical (Mann-Whitney, $p>0,05$ )

Tabela 5 - Eficácia do preparo biomecânico na neutralização da $P$. gingivalis identificada nos canais radiculares de dentes decíduos com polpa necrótica com presença e com ausência de lesão visível radiograficamente na região de furca/periapical.

\begin{tabular}{|c|c|c|c|}
\hline \multirow[t]{2}{*}{ Lesão } & & \multicolumn{2}{|l|}{$P$. gingivalis } \\
\hline & Coleta 1 (C1) & Coleta 2 (C2) & $\Delta \mathrm{C}(\mathrm{C} 1-\mathrm{C} 2)$ \\
\hline $\begin{array}{c}\text { Ausente } \\
\mathrm{n}=12\end{array}$ & $4,30(0,23-14,31)$ a & $0,05(0-0,33) b$ & $3,01(0,05-9,54) \mathrm{A}$ \\
\hline $\begin{array}{c}\text { Presente } \\
\mathrm{n}=20\end{array}$ & $3,61(0,65-27,30)$ a & $0,04(0-2,15) b$ & $3,25(0,63-24,60) \mathrm{A}$ \\
\hline
\end{tabular}

A capacidade da medicação intracanal em eliminar os microrganismos que persistiram nos canais radiculares dos dentes decíduos com polpa necrótica após o preparo biomecânico pode ser observada na Tabela 6 . Na condição necrose sem lesão, para ambas as medicações (hidróxido de cálcio + PEG e hidróxido de cálcio + CLX) não houve diferença significante na concentração de DNA da P.gingivalis detectada nas coletas 2 e 3 (Wilcoxon, 
p>0,05). Ou seja, as duas medicações intracanais mantiveram em C3, níveis de DNA bacteriano semelhantes aqueles encontrados em C2.

Avaliando a condição necrose com lesão, não houve diferença entre as coletas 2 e 3 no grupo do $\mathrm{Ca}(\mathrm{OH})_{2}+$ PEG (Wilcoxon, $\left.\mathrm{p}>0,05\right)$. No grupo do $\mathrm{Ca}(\mathrm{OH})_{2}+\mathrm{CLX}$, foi observada uma maior concentração de DNA bacteriano em C3 quando comparado com C2 (Wilcoxon, p<0,05), sugerindo que esta medicação não impediu o crescimento dos microrganismos que permaneceram no sistema de canais radiculares após o preparo biomecânico.

Com relação à eficácia na redução da $P$. gingivalis $\left(\Delta_{\mathrm{C}}=\mathrm{C} 2-\mathrm{C} 3\right)$, não houve diferença estatística quando foram comparadas as medicações intracanais, pasta de $\mathrm{Ca}(\mathrm{OH})_{2}+$ PEG e pasta de $\mathrm{Ca}(\mathrm{OH})_{2}+\mathrm{CLX}$ aplicadas em dentes com necrose sem lesão (Mann-Whitney, p>0,05). Quando as pastas foram comparadas em dentes com lesão, também não mostraram diferença estatisticamente significativa na quantificação de DNA de $P$. gingivalis (MannWhitney, $\mathrm{p}>0,05)$. Também não houve diferença estatística na eficácia da pasta $\mathrm{Ca}(\mathrm{OH})_{2}+$ PEG quando usada em dentes sem e com lesão (Mann-Whitney, p>0,05). Resultado semelhante também foi observado quando a utilização da pasta de $\mathrm{Ca}(\mathrm{OH})_{2}+\mathrm{CLX}$ foi comparada em dentes sem lesão e com lesão na região de furca/periapical (Mann-Whitney, $\mathrm{p}>0,05$ ). 
Tabela 6 - Efeito da medicação intracanal sobre a P. gingivalis presente nos canais radiculares de dentes decíduos com polpa necrótica com presença e com ausência de lesão visível radiograficamente na região de furca/periapical.

\begin{tabular}{|c|c|c|c|c|}
\hline \multirow[t]{2}{*}{ Lesão } & \multirow[t]{2}{*}{$\begin{array}{l}\text { Medicação } \\
\text { intracanal }\end{array}$} & \multicolumn{3}{|c|}{$\begin{array}{c}\text { P. gingivalis } \\
{[\quad] \text { de DNA }\left(n g \times 10^{6}\right)^{*}}\end{array}$} \\
\hline & & Coleta 2 (C2) & Coleta 3 (C3) & $\Delta \mathrm{C}(\mathrm{C} 2-\mathrm{C} 3)$ \\
\hline \multirow[t]{2}{*}{ Ausente } & $\begin{array}{l}\mathrm{Ca}(\mathrm{OH})_{2}+ \\
\mathrm{PGE}\end{array}$ & $0(0-0,29) \mathrm{a}$ & $0,01(0-1,17) \mathrm{a}$ & $-0,01(-1,10-0,08) \mathrm{AC}$ \\
\hline & $\begin{array}{l}\mathrm{Ca}(\mathrm{OH})_{2}+ \\
\mathrm{CLX}\end{array}$ & $0,14(0-11,17) \mathrm{a}$ & $0,12(0-2,48) \mathrm{a}$ & $-0,03(-1,86-9,56) \mathrm{AD}$ \\
\hline \multirow[t]{2}{*}{ Presente } & $\begin{array}{l}\mathrm{Ca}(\mathrm{OH})_{2}+ \\
\mathrm{PGE}\end{array}$ & $0,4(0-1,10) \quad a$ & $0,35(0-5,13) \mathrm{a}$ & $-0,19(-4,83-0,01) \mathrm{BC}$ \\
\hline & $\begin{array}{l}\mathrm{Ca}(\mathrm{OH})_{2}+ \\
\mathrm{CLX}\end{array}$ & $0,04(0-2,23) \mathrm{a}$ & $3,42(0,45-10,07) b$ & $-2,32(-7,85-(-0,25)) \mathrm{BD}$ \\
\hline
\end{tabular}

* - Mediana (P25-P75)

Letras minúsculas iguais nas linhas denotam ausência de diferença estatística (Wilcoxon, $\mathrm{p}>0,05)$.

Letras maiúsculas iguais na coluna denotam ausência de diferença estatística (MannWhitney, $\mathrm{p}>0,05)$.

\section{Análise Clínica e Radiográfica}

Todos os pacientes foram acompanhados por meio de exames clínico e radiográfico 1, 3 e 6 meses após o tratamento endodôntico.

Dos 16 dentes que receberam o $\mathrm{Ca}(\mathrm{OH})_{2}+$ PEG como medicação intracanal, seis apresentavam-se sem lesão e dez com lesão de furca e/ou periapical no exame inicial. Dos dentes sem lesão, um foi perdido por trauma (avulsão) aos cinco meses de acompanhamento e o outro apresentou insucesso à terapia efetuada, sendo diagnosticada a presença de reabsorção apical na consulta de controle de seis meses pós-operatório. Os outros dentes deste grupo apresentaram sinais clínicos e radiográficos compatíveis com a normalidade 
durante os seis meses de avaliação (Figura 4). Dos dentes com lesão que foram tratados com $\mathrm{Ca}(\mathrm{OH})_{2}+\mathrm{PEG}$, dois foram considerados como insucesso no primeiro mês de pós-operatório, sendo em um deles observada a presença de fístula e, no outro, a presença de tumefação, rubor e dor associados a copiosa secreção purulenta via canal radicular. Os demais dentes deste grupo apresentaram clinicamente ausência de sinais e sintomas e, radiograficamente, redução parcial ou total da lesão de furca/periapical e ausência de reabsorção patológica das raízes durante todo o período de avaliação. 

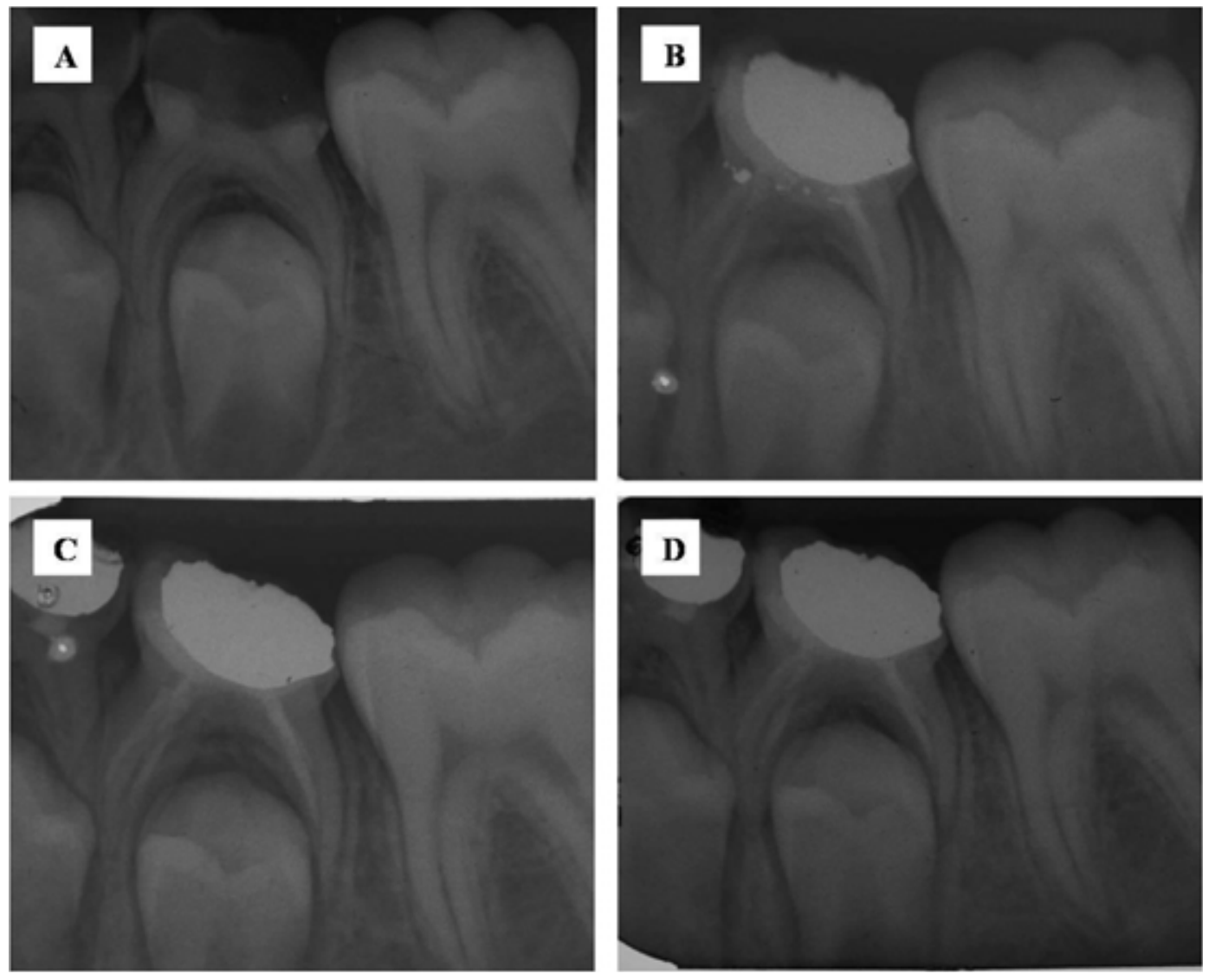

FIGURA 4 - Dente 75 (Grupo I - $\mathrm{Ca}(\mathrm{OH})_{2}+$ PEG) - Sucesso clínico e radiográfico. (A) Aspecto radiográfico inicial; (B) Acompanhamento de um mês; (C) Acompanhamento de três meses; (D) Acompanhamento de seis meses.

A outra metade da amostra (16 dentes - 6 sem lesão e 10 com lesão de furca e/ou periapical) recebeu $\mathrm{Ca}(\mathrm{OH})_{2}+\mathrm{CLX}$ como medicação intracanal. Dos que não apresentavam lesão no exame inicial, um mostrou insucesso radiográfico aos 3 meses, com presença de aumento do espaço do ligamento periodontal e reabsorção radicular (Figura 5). Os demais dentes pertencentes a este grupo apresentaram sinais clínicos e radiográficos compatíveis com a normalidade durante os seis meses de avaliação. Dos dentes que apresentavam 
lesão no exame inicial, dois mostraram insucesso. Desses, um apresentou-se clinicamente normal no exame de três meses de pós-operatório, entretanto, radiograficamente foi observado um aumento do espessamento do espaço do ligamento periodontal associado ao surgimento de lesão periapical relacionada com a raiz mesial. No outro dente, aos seis meses, foi verificada mobilidade patológica associada a reabsorção radicular e aumento da lesão (Figura 6). Os outros oito dentes apresentaram ausência de sinais e sintomas clínicos, redução parcial ou total da lesão de furca/periapical vista radiograficamente (Figura 7) associado a ausência de reabsorção radicular patológica, no período de seis meses de avaliação.
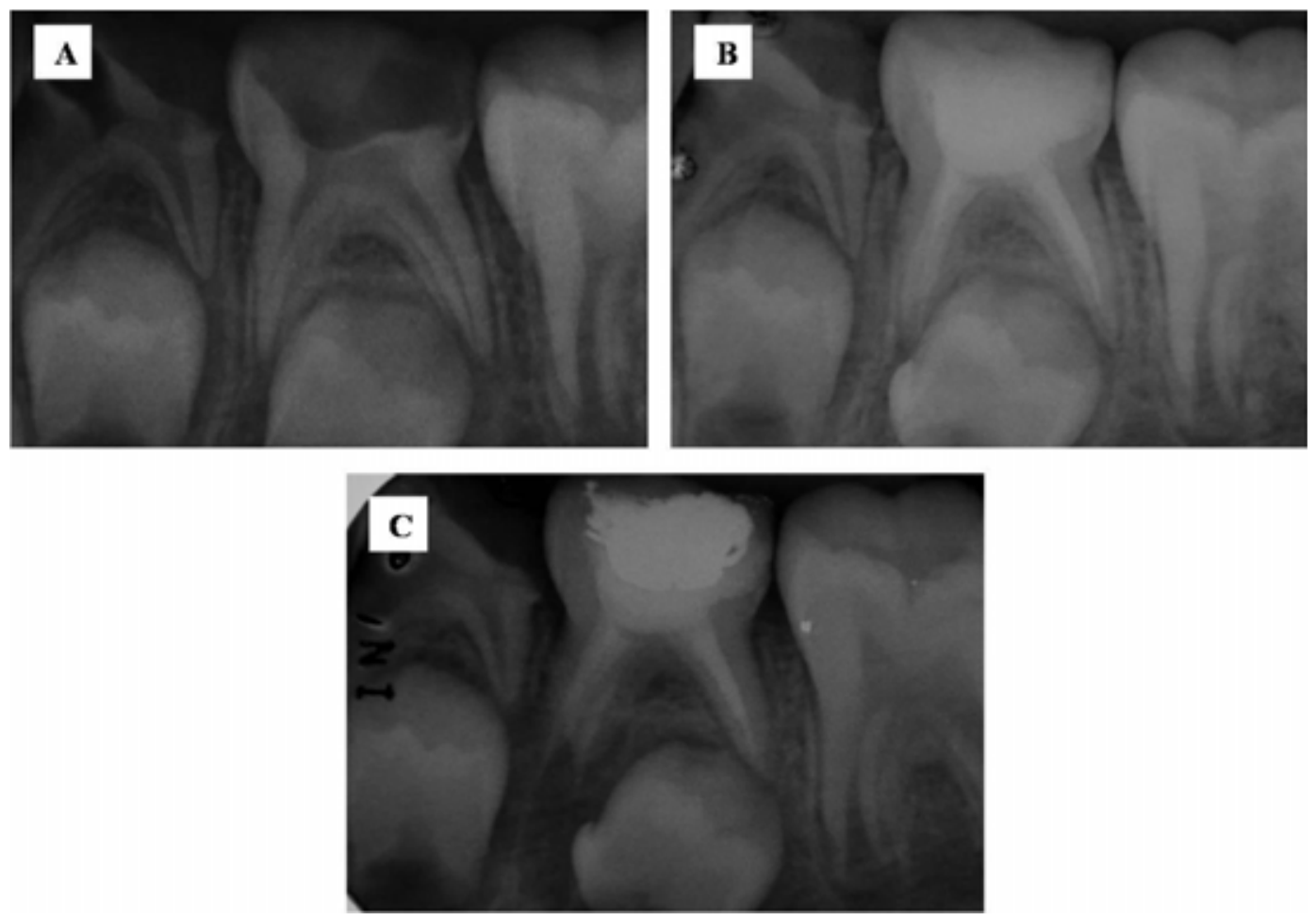

FIGURA 5 - Dente 75 (Grupo I - $\left.\mathrm{Ca}(\mathrm{OH})_{2}+\mathrm{CLX}\right)$. (A) Aspecto radiográfico inicial; (B) Acompanhamento de um mês; (C) Acompanhamento de três meses. Insucesso determinado pelo espessamento do espaço do ligamento periodontal e reabsorção radicular nas raízes mesiais aos 3 meses de pós-operatório. 

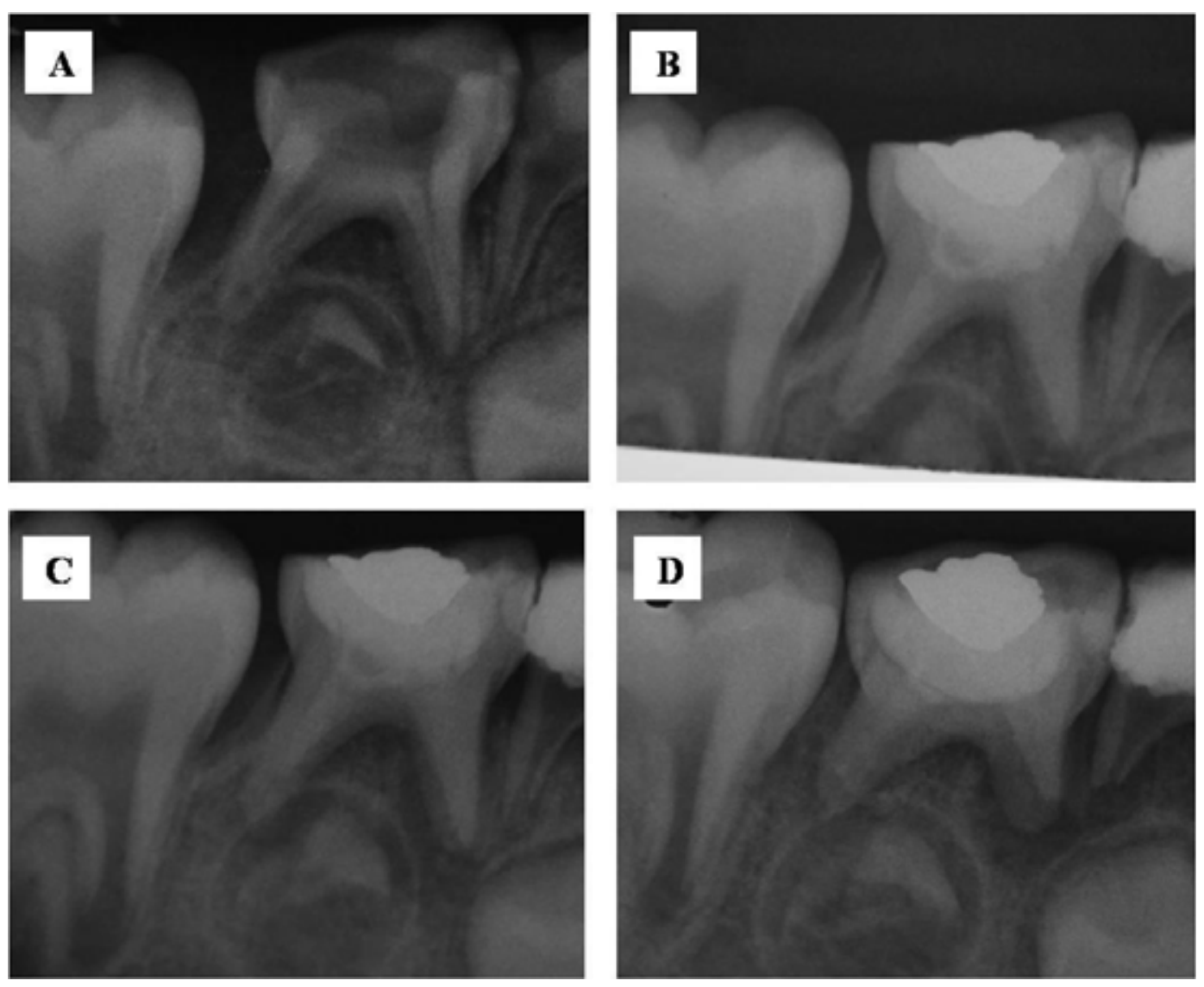

FIGURA 6 - Dente 85 (Grupo II - $\mathrm{Ca}(\mathrm{OH})_{2}+\mathrm{CLX}$ ). (A) Aspecto radiográfico inicial evidenciando a lesão de furca/periapical; (B) Acompanhamento de um mês; (C) Acompanhamento de três meses; (D) Acompanhamento de seis meses. Insucesso determinado pela presença de reabsorção radicular acelerada e aumento da lesão de furca/periapical associado à mobilidade patológica. 

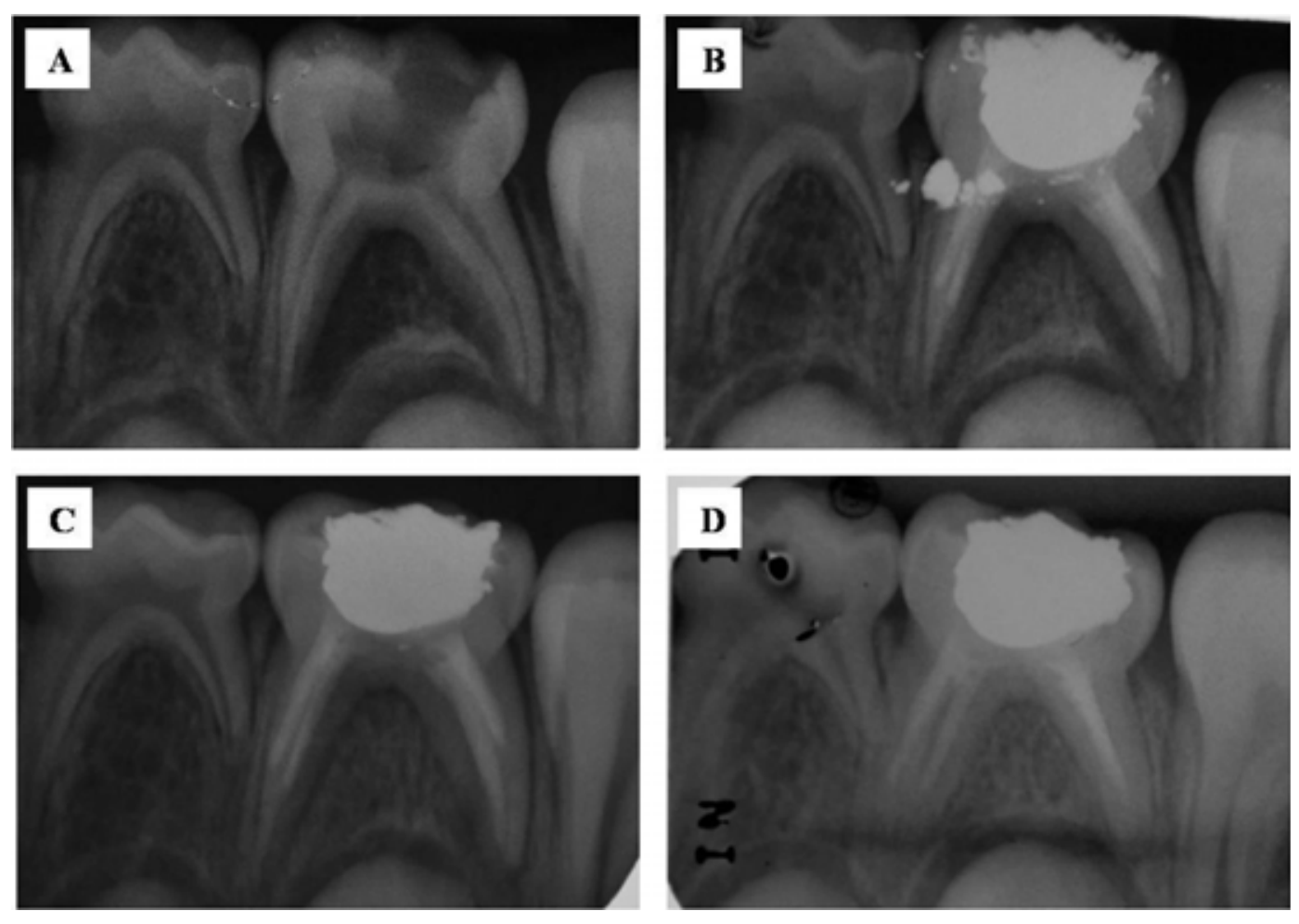

FIGURA 7 - Dente 75 (Grupo II - $\left.\mathrm{Ca}(\mathrm{OH})_{2}+\mathrm{CLX}\right)$. (A) Aspecto radiográfico inicial; (B) Acompanhamento de um mês; (C) Acompanhamento de três meses; (D) Acompanhamento de seis meses. Sucesso clínico e radiográfico, sendo verificado o reparo total da lesão na região de furca/periapical pré-existente aos seis meses de pós-operatório.

A Tabela 7 apresenta a proporção de sucesso clínico e radiográfico para cada grupo da amostra, num período de acompanhamento de seis meses. 
Tabela 7 - Proporção de sucesso clínico e radiográfico de dentes decíduos com polpa necrótica tratados endodônticamente, num período de 6 meses de pós-operatório

\begin{tabular}{lcccc}
\hline Medicação intracanal & \multicolumn{2}{c}{ Período de } & Proporção de \\
& & acompanhamento & sucesso \\
& & Início & 6 meses & \\
\hline \multirow{2}{*}{$\mathrm{Ca}(\mathrm{OH})_{2}+\mathrm{PEG}$} & Sem lesão & 6 & $4^{*}$ & $4 / 5=0,8$ \\
& Com lesão & 10 & 8 & $8 / 10=0,8$ \\
& & & & \\
\hline $\mathrm{Ca}(\mathrm{OH})_{2}+\mathrm{CHX}$ & Sem lesão & 6 & 5 & $5 / 6=0,83$ \\
& Com lesão & 10 & 8 & $8 / 10=0,8$ \\
\hline
\end{tabular}

*um dente sofreu trauma com avulsão aos 5 meses de pós-operatório, sendo excluído da amostra.

Aplicando-se o Teste $\mathrm{Z}$ aos dados da Tabela 7, pode-se observar que não houve diferença entre a proporção de sucesso clínico e radiográfico em dentes sem lesão tratados com $\mathrm{Ca}(\mathrm{OH})_{2}+$ PEG ou com $\mathrm{Ca}(\mathrm{OH})_{2}+\mathrm{CLX}(\mathrm{p}>0,05)$. Também não houve diferença estatística entre a proporção de sucesso clínico e radiográfico em dentes com lesão tratados com $\mathrm{Ca}(\mathrm{OH})_{2}+\mathrm{PEG}$ ou com $\mathrm{Ca}(\mathrm{OH})_{2}$ $+\operatorname{CLX}(\mathrm{p}>0,05)$.

Pode-se observar ainda, que não houve diferença entre a proporção de sucesso clínico e radiográfico comparando-se dentes sem e dentes com lesão tratados com pasta $\mathrm{Ca}(\mathrm{OH})_{2}+\mathrm{PEG}(\mathrm{p}>0,05)$ ou tratados com $\mathrm{Ca}(\mathrm{OH})_{2}+\mathrm{CLX}$. $(\mathrm{p}>0,05)$.

Na Tabela 8 pode-se observar o número de dentes com necrose pulpar sem lesão radiográfica no exame inicial que apresentaram sucesso ou insucesso nos períodos de 1, 3 e 6 meses após tratamento de acordo com o tipo de medicação intracanal 
A Tabela 9 mostra o número de dentes decíduos com polpa necrótica e lesão radiográfica no exame de diagnóstico, com reparo total ou parcial da lesão, assim como, o insucesso da terapia endodôntica de acordo com o tipo de medicação intracanal e período pós-operatório.

Tabela 8 - Frequência cumulativa de dentes com necrose pulpar sem lesão radiográfica (Grupo I) que apresentaram sucesso ou insucesso nos períodos de 1, 3 e 6 meses após tratamento de acordo com o tipo de medicação intracanal

\begin{tabular}{|c|c|c|c|c|c|c|}
\hline \multirow[t]{2}{*}{ Medicação intracanal } & \multicolumn{3}{|c|}{$\begin{array}{c}\text { Sucesso }\left(\mathrm{n}^{0} \text { inicial de }\right. \\
\text { dentes })\end{array}$} & \multicolumn{3}{|c|}{$\begin{array}{c}\text { Insucesso }\left(\mathrm{n}^{\mathrm{o}} \text { inicial de }\right. \\
\text { dentes })\end{array}$} \\
\hline & $1 \mathrm{~m}$ & $3 \mathrm{~m}$ & $6 \mathrm{~m}$ & $1 \mathrm{~m}$ & $3 \mathrm{~m}$ & $6 \mathrm{~m}$ \\
\hline $\mathrm{Ca}(\mathrm{OH})_{2}+\mathrm{PEG}$ & $6(6)$ & $6(6)$ & $4(5)^{*}$ & $0(6)$ & $0(6)$ & $1(5)$ \\
\hline $\mathrm{Ca}(\mathrm{OH})_{2}+\mathrm{CLX}$ & $6(6)$ & $5(6)$ & $5(6)$ & $0(6)$ & $1(6)$ & $1(6)$ \\
\hline
\end{tabular}

*um dente sofreu avulsão devido a traumatismo aos 5 meses de pós-operatório e foi excluído da amostra.

Tabela 9 - Frequência cumulativa de dentes decíduos com necrose pulpar e lesão radiográfica (Grupo II) que apresentaram reparo total, reparo parcial da lesão ou insucesso nos períodos de 1, 3 e 6 meses após tratamento de acordo com o tipo de medicação intracanal

\begin{tabular}{ccccccccccc}
\hline $\begin{array}{c}\text { Medicação } \\
\text { intracanal }\end{array}$ & $1 \mathrm{~m}$ & $3 \mathrm{~m}$ & $6 \mathrm{~m}$ & $1 \mathrm{~m}$ & $3 \mathrm{~m}$ & $6 \mathrm{~m}$ & $1 \mathrm{~m}$ & $3 \mathrm{~m}$ & $6 \mathrm{~m}$ & $\begin{array}{c}\text { Rotal } \\
\text { dentes }\end{array}$ \\
\hline $\mathrm{Ca}(\mathrm{OH})_{2}+$ PEG & 0 & 1 & 2 & 8 & 7 & 6 & 2 & 2 & 2 & 10 \\
$\mathrm{Ca}(\mathrm{OH})_{2}+\mathrm{CLX}$ & 0 & 1 & 1 & 10 & 8 & 7 & 0 & 1 & 2 & 10 \\
Total & 0 & 2 & 3 & 18 & 15 & 13 & 2 & 3 & 4 & 20 \\
\hline
\end{tabular}




\section{DISCUSSÃO}

O presente estudo foi delineado como um ensaio clínico duplo cego visando minimizar a incorporação de vieses que poderiam agir como fatores de confusão e impedir a adequada avaliação da eficácia de materiais e técnicas de tratamento. Assim, os dentes decíduos foram alocados, de acordo com o diagnóstico clínico e radiográfico, em dois grupos: Grupo I (polpa necrótica sem lesão de furca/periapical) e Grupo II (polpa necrótica com lesão de furca/periapical). Após o preparo biomecânico dos canais radiculares, os dentes pertencentes a cada grupo foram distribuídos aleatoriamente, por meio de sorteio, em dois subgrupos, de acordo com a pasta usada como medicação intracanal. Assim, metade da amostra de cada grupo recebeu como medicação intracanal pasta de hidróxido de cálcio p.a. + polietilenoglicol 400, e a outra metade, pasta de hidróxido de cálcio p.a. + clorexidina gel $2 \%$.

Métodos de cultura microbiológica têm sido rotineiramente utilizados para avaliação de procedimentos endodônticos e têm demonstrado que a microbiota dos canais radiculares de dentes com necrose pulpar (infecção primária) consiste principalmente de microrganismos anaeróbios estritos ${ }^{32-33,64-65}$. Técnicas de biologia molecular (reação em cadeia da polimerase - PCR, reação em cadeia da polimerase em "tempo real" - qRT - PCR) têm sido recentemente empregadas na endodontia com o objetivo de identificar microrganismos presentes no interior de canais radiculares com infecções primárias e em casos de retratamento ${ }^{3,7,18,39}$. Comparando as técnicas para avaliação microbiológica, podese observar que a técnica de cultura é deficiente tanto em relação à identificação 
como na quantificação de microrganismos ${ }^{18,47}$. As técnicas de biologia molecular, apesar do alto custo, são mais precisas, rápidas e específicas, sendo capazes de identificar uma maior quantidade de espécies microbiológicas ${ }^{7,18,39,47}$.

Poucos são os trabalhos que avaliam a microbiota dos canais radiculares de dentes decíduos com polpa necrótica ${ }^{7,32,39,51}$ e estes se limitam a verificar os microrganismos em dentes que apresentam lesão periapical crônica. Até o momento, não foram encontrados na literatura trabalhos comparando a microbiota de dentes decíduos com e sem lesão periapical. Desta forma, um dos objetivos deste trabalho foi identificar e quantificar as bactérias $P$. gingivalis $e E$. faecalis em canais radiculares de dentes decíduos com polpa necrótica com e sem lesão radiográfica nos casos de infecção primária por cárie.

A $P$. gingivalis é um bacilo gram-negativo anaeróbio estrito pigmentado de preto comumente encontrado em canais com polpa necrótica que apresentam sensibilidade à percussão. Essa espécie bacteriana foi encontrada em 10 dos 12 dentes necrosados sem lesão e em 18 dos 20 dentes com lesão de furca e/ou periapical. O E. faecalis é um coco gram-positivo anaeróbio facultativo relacionado com a sensibilidade dolorosa e com a presença de lesão periapical ${ }^{7,47}$. Estudos que usam o método de identificação por cultura relatam a presença do $E$. faecalis predominantemente em dentes com insucesso na terapia endodôntica ${ }^{18,47}$. Porém, pesquisas recentes, que utilizam a biologia molecular para análise, mostram que, apesar de em menor quantidade, este microrganismo também pode estar presente em dentes com infecção primária ${ }^{7,18,47}$. No presente estudo, o $E$. faecalis foi encontrado em apenas três dentes, sendo dois sem lesão e um com 
lesão de furca e/ou periapical, semelhante ao que tem sido observado na literatura $^{3,18}$. O E. faecalis foi selecionado para o estudo por estar relacionado aos casos de insucesso de tratamento endodôntico e ser menos sensível ao hidróxido de cálcio usado como medicação intracanal. Assim, uma das hipóteses deste estudo era que a associação do hidróxido de cálcio com a clorexidina aumentaria o seu efeito antibacteriano sobre este microrganismo. Porém, pelo baixo número de amostras contendo o E. faecalis, não foi possível a realização desta análise. Em relação à $P$. gingivalis não foi observada diferença estatisticamente significativa nas concentrações de DNA na primeira coleta em dentes com presença ou não de lesão de furca e/ou periapical.

Para o sucesso do tratamento endodôntico de dentes com polpa necrótica infectados é importante a eliminação dos microrganismos dos canais radiculares, sendo o preparo químico-mecânico e a medicação intracanal empregados com essa finalidade ${ }^{3,33}$. Nos últimos anos, tem ocorrido uma mudança nos paradigmas do tratamento endodôntico de dentes decíduos, sendo atualmente mais freqüente a realização do preparo biomecânico ${ }^{8,31}$. Entretanto, foi encontrado apenas um trabalho na literatura que avalia a efetividade desse procedimento na redução da microbiota intracanal em dentes decíduos ${ }^{13}$. Devido à característica da infecção endodôntica associada às especificidades desses dentes, tais como a complexidade do sistema de canais radiculares, o processo de reabsorção fisiológica e o risco de lesão ao germe dos dentes permanentes sucessores, sugerese que o preparo biomecânico seja incapaz de remover por completo os microrganismos presentes no interior dos canais radiculares. No presente trabalho 
pôde-se observar que o preparo biomecânico associado à irrigação com solução de hipoclorito de sódio a $1 \%$ foi efetivo, determinando uma redução significativa da concentração de DNA da bactéria $P$. gingivalis na coleta 2 em relação aquela observada na coleta $1(\mathrm{p}<0,05)$. Sakamoto et al. ${ }^{42}$ (2007) e Blome et al. ${ }^{3}$ (2008), por meio do PCR em tempo real, também observaram uma redução significante de microrganismos após preparo biomecânico de dentes permanentes. Apesar destes resultados, verificou-se no presente trabalho que 18 dos 28 dentes que apresentavam microrganismos na coleta 1 ainda apresentavam algum grau de contaminação na coleta 2 , ressaltando a dificuldade de desinfecção dos canais radiculares dos dentes decíduos.

Vale salientar que a coleta microbiológica realizada imediatamente após o preparo biomecânico evidencia o estado do canal principal, entretanto, podem existir colônias bacterianas residuais nos túbulos dentinários, canais secundários e acessórios e nas crateras de reabsorção. Além disso, diferenças são, geralmente, encontradas quando são comparados os resultados apresentados pelos diferentes estudos com relação a porcentagem de microrganismos detectados após o preparo biomecânico. Estas diferenças podem ser atribuídas ao tipo e concentração das soluções irrigadoras, aos sistemas de irrigação, às técnicas de avaliação microbiológica utilizadas e ao tipo de dentes analisados ${ }^{44}$. Somado a isso, podem existir variações anatômicas nos canais radiculares que dificultam o acesso das limas e soluções irrigadoras favorecendo a permanência de restos necróticos e infectados ${ }^{3,33,42}$. 
À semelhança do que ocorre em dentes permanentes, nos dentes decíduos o hidróxido de cálcio está entre os materiais de escolha para medicação intracanal ${ }^{3,6,8,31,33,42,44}$. Por ser altamente alcalino ( $\mathrm{pH}$ aproximado 12,5), várias propriedades biológicas são atribuídas a esta substância, tais como: ação antimicrobiana, inativação do LPS, inibição de reabsorção radicular e indução de reparo pela formação de tecido duro ${ }^{17,44,58}$.

A ação antimicrobiana do hidróxido de cálcio está relacionada principalmente com a liberação de íons hidroxila e conseqüente alcalinização do meio, quando em solução aquosa ${ }^{58}$. Estes íons atuam como radicais livres de alta reatividade promovendo ação letal sobre as bactérias ${ }^{16-17,44}$. De acordo com a literatura, a $P$. gingivalis apresenta crescimento estável em ambiente no qual o $\mathrm{pH}$ encontra-se entre 8,0 e 8,3, enquanto que alguns Enterococcus apresentam maior tolerância, podendo sobreviver em ambientes com $\mathrm{pH}$ variando de 9 a $11^{16-17,34,58}$. Assim, a maioria dos microrganismos presentes no interior dos canais radiculares de dentes com necrose da polpa é incapaz de sobreviver em ambiente altamente alcalino provido pelo hidróxido de cálcio ${ }^{16-17,34}$.

Após 30 dias de permanência do curativo de demora de hidróxido de cálcio no interior dos canais, era esperado que este fosse capaz de eliminar ou reduzir abruptamente a infecção residual. Entretanto, no presente trabalho, em relação a $P$.gingivalis, não foi observada diferença estatística entre a coleta 2 (C2), realizada imediatamente após o preparo biomecânico e a coleta 3 (C3), três dias após a remoção da medicação intracanal, independente da presença ou não de lesão. Estes resultados estão de acordo com os apresentados por Peters et al. ${ }^{33}$ 
(2002), Sakamoto et al. ${ }^{42}$ (2007) e Blome et al. ${ }^{3}$ (2008) que não encontraram diferença significante na concentração de DNA bacteriano entre as coletas após o preparo biomecânico e após a medicação com hidróxido de cálcio. Desta forma, supõe-se que uma única aplicação do hidróxido de cálcio e manutenção intracanal por 30 dias, não confere ação bactericida suficiente para a erradicação dos microrganismos presentes. Este resultado pode ser atribuído ao fato de o hidróxido de cálcio apresentar ação antimicrobiana dose-dependente $e^{30,57,67}$. Além disso, a dentina exerce capacidade tampão ${ }^{30,67}$ e alguns microrganismos apresentam mecanismos inerentes de proteção ${ }^{20}$.

Para atuar como medicação intracanal de forma efetiva no caso de dentes com polpa necrótica, o hidróxido de cálcio precisa difundir pelos túbulos dentinários em concentração adequada para eliminar os microrganismos. Entretanto, a dentina é composta por íons fosfato e bicarbonato, proteínas e dióxidos de carbono, os quais podem atuar como tampão, neutralizando os íons hidroxila $^{57,60,67}$. Substâncias presentes nos fluidos teciduais de lesões periapicais também podem impedir o aumento da concentração dos íons hidroxila ${ }^{57-58,60,67}$. Desta forma, para alcançar nível de $\mathrm{pH}$ capaz de eliminar os microrganismos no interior dos túbulos dentinários, a difusão iônica do hidróxido de cálcio deve exceder a capacidade tampão do tecido dentário, bem como, a ação neutralizadora dos fluidos teciduais ${ }^{30}$.

A disposição dos microrganismos que compõem o biofilme dos canais radiculares também limita a ação bactericida do hidróxido de cálcio. Dessa forma, as bactérias localizadas nas camadas mais internas do biofilme são 
protegidas por aquelas situadas na sua periferia ${ }^{56}$. Além disso, alguns microrganismos podem apresentar mecanismos de adaptação por meio de síntese protéica, aumentando assim a sua resistência em meio alcalino e o tempo de sobrevida $^{20}$.

O objetivo do tratamento endodôntico não se resume apenas na eliminação de bactérias, mas também em inativar suas endotoxinas. $\mathrm{O}$ lipopolissacarídeo (LPS), endotoxina presente na parede celular de bactérias gram-negativas, é um dos fatores responsáveis por desencadear e manter o processo inflamatório e a reabsorção óssea na região de periápice ${ }^{52}$. Tem sido demonstrado que a solução de hipoclorito de sódio e a clorexidina usadas como soluções irrigadoras auxiliam na redução do LPS, mas não o eliminam completamente ${ }^{50,66}$. Assim, é importante selecionar, para curativo intracanal, um medicamento que também seja capaz de inativar os produtos e subprodutos bacterianos localizados nos túbulos dentinários e crateras de reabsorção. Neste sentido, o poder do hidróxido de cálcio em neutralizar o LPS tem sido evidenciado por diversas pesquisas ${ }^{40-41,52,66}$.

Segundo Vianna et al. ${ }^{68}$ (2005) e Gomes et al. ${ }^{17}$ (2006) as bactérias anaeróbias estritas são mais sensíveis a medicação intracanal do que as aeróbias e anaeróbias facultativas. Apesar disso, o hidróxido de cálcio requer um período de tempo para elevar o $\mathrm{pH}$ local até um nível que exerça efeito bactericida ${ }^{17}$. Contudo existem controvérsias em relação ao tempo necessário de permanência do material intracanal para tornar o ambiente asséptico ${ }^{3,5,19,31,42,62}$. Onçag et al. ${ }^{31}$ (2006) demonstraram o crescimento de microrganismos após 48h de efeito da 
medicação intracanal. Sjogren et al. $^{62}$ (1991) relataram que uma semana de curativo de hidróxido de cálcio é suficiente para a eliminação das bactérias do interior dos canais radiculares. Entretanto, outras pesquisas demonstraram a permanência de bactérias após o uso desta medicação durante uma semana, mostrando que neste período de tempo, ela é incapaz de atingir microrganismos localizados na superfície radicular externa ao canal radicular ${ }^{19,26,42}$. Blome et al. ${ }^{3}$ (2008) em um estudo in vivo também demonstraram que 2 semanas de uso do hidróxido de cálcio, não é um período satisfatório para erradicação dos microrganismos.

Bystrom et al. $^{5}$ (1985) sugeriram um período de permanência da medicação intracanal de 4 semanas, o qual pode ser suportado pelo trabalho de Nerwich et al. ${ }^{30}$ (1993), que demonstrou a difusão dos íons hidroxila através da dentina radicular, atingindo altos níveis tanto na região cervical como na apical da raiz e determinando um pH estável na superfície radicular após esse período de tempo. No presente trabalho, o hidróxido de cálcio com polietilenoglicol permaneceu no interior dos canais radiculares por um período de 4 semanas (30 dias) e , mesmo assim, pode-se verificar a presença de crescimento bacteriano em quatro dos seis dentes decíduos com polpa necrótica sem lesão na região de furca/periapical e em sete dos dez dentes com polpa necrótica e lesão. Resultado semelhante foi observado por Peters et al. $^{33}$ (2002), no qual também foi encontrado crescimento de microrganismos após a permanência da medicação de hidróxido de cálcio por 4 semanas. 
O fato de o hidróxido de cálcio ser capaz de se difundir pelos túbulos dentinários e tornar o ambiente alcalino é de fundamental importância no tratamento de dentes com polpa necrótica com reabsorção radicular patológica tanto por cárie como por trauma, visto que, o alto $\mathrm{pH}$ além de ser bactericida, inibe a atividade osteoclástica ${ }^{30,67}$.

O baixo poder bactericida sobre o E. faecalis apresentado pelo hidróxido de cálcio fez com que algumas substâncias fossem adicionadas a este material para aumentar sua ação antibacteriana e conseqüente sucesso endodôntico. A clorexidina tem sido amplamente utilizada na odontologia por apresentar característica antibacteriana de amplo espectro e substantividade ${ }^{29}$. Sua associação com o hidróxido de cálcio tem sido pesquisada, visto ter sido demonstrada ação letal da clorexidina sobre o E. faecalis $^{17,19,29,31}$. Contudo, ainda não existe um consenso na literatura em relação a concentração ideal de clorexidina a ser incorporada ao hidróxido de cálcio ${ }^{10,19,29,31}$. Diversas pesquisas in vitro e in vivo realizadas em dentes permanentes têm usado diferentes concentrações de clorexidina tanto na forma isolada como em associação ao hidróxido de cálcio ${ }^{17,19,29}$. Entretanto, estudos com relação ao tratamento endodôntico em dentes decíduos são escassos ${ }^{31}$. Diante disso, no presente trabalho optou-se por utilizar a clorexidina na forma de gel, numa concentração de $2 \%$ associada ao hidróxido de cálcio p.a. como medicação intracanal em dentes decíduos necrosados, em função de alguns trabalhos apresentarem resultados promissores ${ }^{17,19,26,69}$. Gomes et al. ${ }^{17}$ (2006) demonstraram que a clorexidina gel a $2 \%$ é capaz de eliminar completamente o crescimento bacteriano após permanecer 
em contato direto por um minuto com o E. faecalis e por 15 segundos com a $P$. gingivalis. Quando associada ao hidróxido de cálcio, os tempos requeridos foram de um minuto e de 30 segundos, respectivamente para o E. faecalis e para a $P$. gingivalis. Quando avaliado o hidróxido de cálcio associado à água, para inibir o crescimento dessas bactérias foi necessário um contato direto por 24 horas para o E. faecalis e por 30 segundos para a $P$. gingivalis.

As metaloproteinases (MMPs) são enzimas responsáveis pela degradação da matriz extracelular e estão presentes de forma regulada nos tecidos normais do hospedeiro. Na presença de um processo inflamatório, estas enzimas encontram-se em desequilíbrio, tendo sido fortemente relacionadas com o processo de reabsorção óssea associado à lesão periapical ${ }^{23}$. Tem sido demonstrado que, mesmo em baixas concentrações, a clorexidina atua como inibidor sintético de $\mathrm{MMPs}^{15}$. Desta forma, a incorporação da clorexidina ao hidróxido de cálcio como medicação intracanal também tem como finalidade inibir as metaloproteinases envolvidas na reabsorção óssea na região de periápice de dentes com polpa necrótica, favorecendo o reparo tecidual .

O poder antimicrobiano da clorexidina parece ser reduzido quando ela é incorporada ao hidróxido de cálcio e, embora alguns estudos tenham demonstrado que o efeito antibacteriano do hidróxido de cálcio seja significantemente aumentado com a sua adição ${ }^{11,17,19,31,34}$, outros não observaram este sinergismo de ação ${ }^{2,10,26,46}$. No presente estudo, a associação do hidróxido de cálcio com a clorexidina não se mostrou mais efetiva do que o hidróxido de cálcio 
com PEG em eliminar os microrganismos do sistema de canais radiculares independente da presença ou não de lesão.

Avaliando-se os dentes sem lesão, o uso da associação do hidróxido de cálcio com a clorexidina não mostrou diferença estatisticamente significante na concentração de DNA de $P$. gingivalis entre as coletas 2 e 3 . Entretanto, nos dentes com lesão, as concentrações de DNA bacteriano foram estatisticamente superiores na coleta 3 em relação a coleta $2(\mathrm{p}<0,05)$. Para o $E$. faecalis, dos 16 dentes tratados com essa medicação, apenas um dente sem lesão radiográfica apresentou essa espécie bacteriana em C1. Em C2 esse microrganismo não foi identificado e a associação do hidróxido de cálcio com a clorexidina conseguiu manter este resultado. Em um estudo in vivo realizado em dentes decíduos necrosados, Onçag et al. ${ }^{31}$ (2006) obtiveram melhores resultados sobre o E. faecalis usando clorexidina gel $1 \%$ ou a sua associação com o hidróxido de cálcio quando comparado ao hidróxido de cálcio puro. Manzur et al. $^{26}$ (2007), em um estudo in vivo em dentes permanentes, não encontraram diferença estatística ao avaliar a ação antibacteriana da clorexidina gel 2\%, do hidróxido de cálcio e da associação de ambos medicamentos.

A ausência de ação antibacteriana adicional observada no presente estudo quando a clorexidina foi incorporada ao hidróxido de cálcio pode ser devido à diferença de $\mathrm{pH}$ de atuação destes dois compostos. A atividade antibacteriana da clorexidina é $\mathrm{pH}$ dependente, com $\mathrm{pH}$ ótimo variando entre 5,5 e $7,0^{28-29}$. Alguns estudos relatam que a clorexidina por ser instável em $\mathrm{pH}$ alcalino tende a precipitar ${ }^{2,69}$, e pode ocorrer ligação entre as moléculas de clorexidina e os 
íons hidroxila do hidróxido de cálcio com conseqüente inibição da liberação da molécula de clorexidina ${ }^{2}$. A clorexidina é capaz de interagir com componentes orgânicos expostos da dentina, principalmente com proteínas da matriz, o que pode também limitar sua ação ${ }^{35-36}$. Além disso, foi demonstrado por Grenier et al. $^{20}$ (1995) que a membrana celular de algumas cepas da $P$. gingivalis é capaz de produzir e liberar vesículas que inibem o efeito antibacteriano da clorexidina, protegendo assim essa e outras espécies bacterianas da ação letal desta substância.

Algumas pesquisas avaliam a eficácia bactericida da medicação intracanal logo após sua remoção ${ }^{3,26,31,33,42}$. Entretanto, a coleta realizada neste momento reflete a condição imediata do canal principal. Para que esta amostra represente o estado microbiológico real do sistema de canais radiculares é necessário que o canal radicular permaneça vazio durante um período de tempo associado ao adequado selamento da $\operatorname{coroa}^{63}$. Com esse procedimento, os microorganismos que resistem ao preparo biomecânico e à medicação intracanal, proliferam e recolonizam as paredes do canal radicular, sendo capazes de atingir níveis numéricos equivalentes aqueles encontrados antes do tratamento endodôntico ${ }^{63}$. No presente trabalho, a eficácia de ambas as medicações intracanal foi avaliada $72 \mathrm{~h}$ após sua remoção, sendo observada a permanência de microrganismos na maioria dos casos.

Desta forma, a detecção de bactérias após o período de permanência das medicações intracanal $\left(3^{\mathrm{a}}\right.$ coleta) pode ter sido devido a proliferação de microrganismos residuais provenientes dos túbulos dentinários, crateras de reabsorção e regiões inacessíveis à medicação ${ }^{63}$. Outras hipóteses para 
este resultado podem ser sugeridas, tais como, a neutralização das medicações intracanal por componentes teciduais, o desenvolvimento de fatores de resistência bacteriana e alterações na expressão gênica que permitem que os microrganismos sobrevivam em ambientes com condições desfavoráveis ${ }^{19-20}$.

A avaliação clinica e radiográfica dos dentes decíduos com polpa necrótica realizada durante um período de seis meses evidenciou um baixo percentual de insucesso, sendo demonstrado que não houve diferença entre a proporção de sucesso clínico e radiográfico em dentes com e sem lesão radiográfica que receberam como curativo intracanal hidróxido de cálcio em polietilenoglicol ou hidróxido de cálcio associado à clorexidina, e foram obturados com pasta de hidróxido de cálcio em polietilenoglicol. Numa visão panorâmica, quatro dos vinte dentes com lesão radiográfica (20\%) apresentaram insucesso a terapia instituída, sendo observado um reparo total da área de lesão em $15 \%$ e parcial em $65 \%$ dos dentes avaliados. Ercan et al. ${ }^{10}$ (2007) avaliaram, por meio de exames clínico e radiográfico por 12 meses, o efeito da associação do hidróxido de cálcio com clorexidina como medicação intracanal em dentes permanentes com necessidade de retratamento endodôntico. Estes autores observaram 64\% de reparo total, $14 \%$ de reparo parcial e $22 \%$ de insucesso. Coser et al. ${ }^{8}$ (2008) avaliaram durante quatro anos o efeito do hidróxido de cálcio no tratamento de dentes decíduos necrosados com perda óssea na região de furca observando significante redução ou reparo total da lesão nos primeiros 12 meses de acompanhamento. 
A redução parcial da lesão ou a persistência dos sinais e sintomas depois de um tempo adequado para que ocorra o reparo total após a realização do tratamento endodôntico pode ser resultado da permanência de microrganismos residuais, porém este assunto tem sido pouco pesquisado em relação aos dentes decíduos $^{3,42,55,63}$. Desta forma, é importante incentivar pesquisas laboratoriais e clínicas para uma contínua busca por uma medicação intracanal ideal para dentes decíduos, dando ênfase às suas particularidades e à condição comportamental do paciente infantil. Este achado representaria uma importante contribuição para se estabelecer um protocolo para o tratamento endodôntico desses dentes nas diferentes Instituições de Ensino, contribuindo para reduzir a insegurança dos profissionais no momento de realizar a terapia pulpar em dentes decíduos com polpa necrótica. 


\section{CONCLUSÃO}

1 - Não houve diferença no efeito antibacteriano sobre a $P$. gingivalis entre a pasta de hidróxido de cálcio associada a clorexidina e a pasta de hidróxido de cálcio em polietilenoglicol, quando usadas como medicação intracanal no tratamento de dentes decíduos com polpa necrótica na presença ou na ausência de lesão de furca e/ou periapical.

2 - Apesar de não ter ocorrido a eliminação completa dos microrganismos $P$. gingivalis e E. faecalis presentes no interior dos canais radiculares de dentes decíduos humanos com necrose da polpa sem e com lesão radiográfica na região de furca e/ou periapical submetidos ao tratamento endodôntico utilizando hidróxido de cálcio associado ou não à clorexidina como medicação intracanal, ambas as pastas estudadas determinaram elevado índice de sucesso clínico e radiográfico. 


\section{REFERENCIAS}

1. Aminabadi NA, Farahani RM, Gajan EB. Study of root canal accessibility in human primary molars. J Oral Sci. 2008; 50: 69-74.

2. Ballal V, Kundabala M, Acharya S, Ballal M. Antimicrobial action of calcium hydroxide, chlorhexidine and their combination on endodontic pathogens. Aust Dent J. 2007; 52: 118-21.

3. Blome B, Braun A, Sobarzo V, Jepsen S. Molecular identification and quantification of bacteria from endodontic infections using real-time polymerase chain reaction. Oral Microbiol Immunol. 2008; 23: 384-90.

4. Brusco EHC, Perussolo B, Scapin HLC, Ferreira SLM. Procedimentos e substâncias empregadas por Faculdades de Odontologia Brasileiras na terapia endodôntica de dentes decíduos pulpectomizadas. J Bras Odontopediatr Odontol Bebê. 2002; 5: 35-46.

5. Bystrom A, Claesson R, Sundqvist G. The antibacterial effect of camphorated paramonochlorophenol, camphorated phenol and calcium hydroxide in the treatment of infected root canals. Endod Dent Traumatol. $1985 ; 1: 170-5$.

6. Carrotte PV, Waterhouse PJ. A clinical guide to endodontics - update part 2. Br Dent J. 2009; 206: 133-9.

7. Cogulu D, Uzel A, Oncag O, Eronat C. PCR-based identification of selected pathogens associated with endodontic infections in deciduous and permanent teeth.Oral Surg Oral Med Oral Pathol Oral Radiol Endod. 2008; 106: 443-9.

* De acordo com o Estilo Vancouver. Disponível no site: http://www.nlm.nih.gov/bsd/uniform_requirements.html 
8. Coser RM, Gondim JO, Giro EMA. Evaluation of 2 endodontic techniques used to treat human primary molars with furcation radiolucency area: A 48-month radiographic study. Quintessence Int. 2008; 39: 549-57.

9. Ercan E, Dalli M, Dulgergil CT. In vitro assessment of the effectiveness of chlorhexidine gel and calcium hydroxide paste with chlorhexidine against Enterococcus faecalis and Candida albicans. Oral Surg Oral Med Oral Pathol Oral Radiol Endod. 2006; 102: e27-31.

10. Ercan E, Dalli M, Dulgergil CT, Yaman F. Effect of intracanal medication with calcium hydroxide and $1 \%$ chlorhexidine in endodontic retreatment cases with periapical lesions: an in vivo study. J Formos Med Assoc. 2007; 106: 217-24.

11. Evans MD, Baumgartner JC, Khemaleelakul SU, Xia T. Efficacy of calcium hydroxide: chlorhexidine paste as an intracanal medication in bovine dentin. J Endod. 2003; 29: 338-9.

12. Fabricius L, Dahlén G, Ohman AE, Möller AJ. Predominant indigenous oral bacteria isolated from infected root canals after varied times of closure. Scand J Dent Res. 1982; 90: 134-44.

13. Faria G. Prevalência de microrganismos em canais radiculares de dentes decíduos de humanos portadores de necrose pulpar e lesão periapical. Efeito do preparo biomecânico e do curativo de demora à base de hidróxido de cálcio [Dissertação de mestrado]. Ribeirão Preto: Faculdade de Odontologia da USP; 2001. 
14. Fox AG, Heeley JD. Histological study of pulps of human primary teeth. Arch Oral Biol. 1980; 25: 103-10.

15. Gendron R, Grenier D, Sorsa T, Mayrand D. Inhibition of the activities of matrix metalloproteinases 2, 8, and 9 by chlorhexidine. Clin Diagnost Lab Immunol. 1999; 6: 437-9.

16. Georgopoulou M, Kontakiotis E, Nakou M. In vitro evaluation of the effectiveness of calcium hydroxide and paramonochlorophenol on anaerobic bacteria from the root canal. Endod Dent Traumatol. 1993; 9: 249-53.

17. Gomes BP, Vianna ME, Sena NT, Zaia AA, Ferraz CC, de Souza Filho FJ. In vitro evaluation of the antimicrobial activity of calcium hydroxide combined with chlorhexidine gel used as intracanal medicament. Oral Surg Oral Med Oral Pathol Oral Radiol Endod. 2006; 102: 544-50.

18. Gomes BP, Pinheiro ET, Sousa EL, Jacinto RC, Zaia AA, Ferraz CC, et al. Enterococcus faecalis in dental root canals detected by culture and by polymerase chain reaction analysis. Oral Surg Oral Med Oral Pathol Oral Radiol Endod. 2006; 102: 247-53.

19. Gomes BP, Montagner F, Berber VB, Zaia AA, Ferraz CC, de Almeida JF, et al. Antimicrobial action of intracanal medicaments on the external root surface. J Dent. 2009; 37: 76-81.

20. Grenier D, Bertrand J, Mayrand D. Porphyromonas gingivalis outer membrane vesicles promote bacterial resistance to chlorhexidine. Oral Microbiol Immunol.1995; 10: 319-20. 
21. Khademi AA, Mohammadi Z, Havaee A. Evaluation of the antibacterial substantivity of several intra-canal agents. Aust Endod J. 2006; 32: 112-5.

22. Lenet BJ, Komorowski R, Wu XY, Huang J, Grad H, Lawrence HP, et al. Antimicrobial substantivity of bovine root dentin exposed to different chlorhexidine delivery vehicles. J Endod. 2000; 26: 652-5.

23. Leonardi R, Caltabiano R, Loreto C. Collagenase-3 (MMP-13) is expressed in periapical lesions: an immunohistochemical study. Int Endod J. 2005; 38: 297-301.

24. Lessa FCR. Citotoxicidade direta e transdentinária da clorexidina sobre células odontoblastóides MDPC-23 e análise antibacteriana in vitro [Tese de doutorado]. Araraquara: Faculdade de Odontologia de Araraquara UNESP; 2008.

25. Maeda H, Fujimoto C, Haruki Y, Maeda T, Kokeguchi S, Petelin M, et al. Quantitative real-time PCR using TaqMan and SYBR Green for Actinobacillus actinomycetemcomitans, Porphyromonas gingivalis, Prevotella intermedia, tetQ gene and total bacteria. FEMS Immunol Med Microbiol. 2003; 39: 81-6.

26. Manzur A, Gonzalez AM, Pozos A, Silva-Herzog D, Friedman S. Bacterial quantification in teeth with apical periodontitis related to instrumentation and different intracanal medications: a randomized clinical trial. J Endod. 2007; 33: 114-8. 
27. Mattuella LG, Poli de Figueiredo JA, Nör JE, de Araujo FB, Medeiros Fossati AC. Vascular endothelial growth factor receptor-2 expression in the pulp of human primary and young permanent teeth. J Endod. 2007; 33: 1408-12.

28. McDonnell G, Russell AD. Antiseptics and disinfectants: activity, action, and resistance. Clin Microbiol Rev. 1999; 12: 147-79.

29. Mohammadi Z, Abbott PV. The properties and applications of chlorhexidine in endodontics. Int Endod J. 2009; 42: 288-302.

30. Nerwich A, Figdor D, Messer HH. pH changes in root dentin over a 4week period following root canal dressing with calcium hydroxide. J Endod. 1993; 19: 302-6.

31. Onçag O, Gogulu D, Uzel A. Efficacy of various intracanal medicaments against Enterococcus faecalis in primary teeth: an in vivo study. J Clin Pediatr Dent. 2006; 30: 233-7.

32. Pazelli LC, Freitas AC, Ito IY, Souza-Gugelmin MC, Medeiros AS, Nelson-Filho P. Prevalence of microorganisms in root canals of human deciduous teeth with necrotic pulp and chronic periapical lesions. Pesqui Odontol Bras. 2003; 17: 367-71.

33. Peters LB, Van Winkelhoff AJ, Buijs JF, Wesselink PR. Effects of instrumentation, irrigation and dressing with calcium hydroxide on infected in pulpless teeth with periapical bone lesions. Int Endod J. 2002; 35: 13-21. 
34. Podbielski A, Spahr A, Haller B. Additive antimicrobial activity of calcium hydroxide and chlorhexidine on common endodontic bacterial pathogens. J Endod. 2003; 29: 340-5.

35. Portenier I, Haapasalo H, Orstavik D, Yamauchi M, Haapasalo M. Inactivation of the antibacterial activity of iodine potassium iodide and chlorhexidine digluconate against Enterococcus faecalis by dentin, dentin matrix, type-I collagen, and heat-killed microbial whole cells. J Endod. 2002; 28: 634-7.

36. Portenier I, Haapasalo H, Rye A, Waltimo T, Ørstavik D, Haapasalo M. Inactivation of root canal medicaments by dentine, hydroxylapatite and bovine serum albumin. Int Endod J. 2001; 34: 184-8.

37. Rasmussen R. Quantification on the LightCycler. In Meuer S, Wittwer C, Nagawara K. (eds.), Rapid Cycle Real-time PCR. Methods and Applications. Heidelberg: Springer Press, 2001. p. 21-34.

38. Rossi A, Silva LA, Leonardo MR, Rocha LB, Rossi MA. Effect of rotary or manual instrumentation, with or without a calcium hydroxide/1\% chlorhexidine intracanal dressing, on the healing of experimentally induced chronic periapical lesions. Oral Surg Oral Med Oral Pathol Oral Radiol Endod. 2005; 99: 628-36.

39. Ruviére DB, Leonardo MR, da Silva LA, Ito IY, Nelson-Filho P. Assessment of the microbiota in root canals of human primary teeth by checkerboard DNA-DNA hybridization. J Dent Child. 2007; 74: 118-23. 
40. Safavi KE, Nichols FC. Effect of calcium hydroxide on bacterial lipopolysaccharide. J Endod. 1993; 19: 76-8.

41. Safavi KE, Nichols FC. Alteration of biological properties of bacterial lipopolysaccharide by calcium hydroxide treatment. J Endod. 1994; 20: $127-9$.

42. Sakamoto M, Siqueira Jr JF, Rôças IN, Benno Y. Bacterial reduction and persistence after endodontic treatment procedures. Oral Microbiol Immunol. 2007; 22: 19-23.

43. Sanchez IR, Nusbaum KE, Swaim SF, Hale AS, Henderson RA, McGuire JA. Chlorhexidine diacetate and povidone-iodine cytotoxicity to canine embryonic fibroblasts and Staphylococcus aureus. Vet Surg. 1988; 17: $182-5$.

44. Sathorn C, Parashos P, Messer H. Antibacterial efficacy of calcium hydroxide intracanal dressing: a systematic review and meta-analysis. Int Endod J. 2007; 40: 2-10.

45. Scavuzzi AI, Junior AD, Couto GB, Vasconcelos MM, Soares RP, Valenca PA. Longitudinal study of dental caries in Brazilian children aged from 12 to 30 months. Int J Paediatr Dent. 2007; 17: 123-8.

46. Schäfer E, Bössmann K. Antimicrobial efficacy of chlorhexidine and two calcium hydroxide formulations against Enterococcus faecalis. J Endod. 2005; 31: 53-6. 
47. Sedgley C, Nagel A, Dahlén G, Reit C, Molander A. Real-time quantitative polymerase chain reaction and culture analyses of Enterococcus faecalis in root canals. J Endod. 2006; 32: 173-7.

48. Shovelton DS. The presence and distribution of microorganisms within non-vital teeth. Braz Dent J. 1964; 117: 101-7.

49. Silva LA, Leonardo MR. Qual a orientação para tratamento endodôntico dos dentes decíduos? Rev Assoc Paul Cirurg Dent. 1995; 49: 385.

50. Silva LA, Leonardo MR, Assed S, Tanomaru Filho M. Histological study of the effect of some irrigating solutions on bacterial endotoxin in dogs. Braz Dent J. 2004; 15: 109-14.

51. Silva LA, Nelson-Filho P, Faria G, de Souza-Gugelmin MC, Ito IY. Bacterial profile in primary teeth with necrotic pulp and periapical lesions. Braz Dent J. 2006; 17: 144-8.

52. Silva LA, da Silva RA, Branco LG, Navarro VP, Nelson-Filho P. Quantitative radiographic evaluation of periapical bone resorption in dog's teeth contaminated with bacterial endotoxin (LPS) associated or not with calcium hydroxide. Braz Dent J. 2008; 19: 296-300.

53. Simpson WJ. An examination of root canal anatomy of primary teeth. J Can Dent Assoc. 1973; 39: 637-40.

54. Siqueira JF Jr. Endodontic infections: concepts, paradigms, and perspectives. Oral Surg Oral Med Oral Pathol Oral Radiol Endod. 2002; 94: 281-93. 
55. Siqueira Jr JF. Microbial causes of endodontic flare-ups. Int Endod J. 2003; 36: 453-63.

56. Siqueira Jr JF, de Uzeda M. Disinfection by calcium hydroxide pastes of dentinal tubules infected with two obligate and one facultative anaerobic bacteria. J Endod. 1996; 22: 674-6.

57. Siqueira Jr JF, de Uzeda M. Influence of different vehicles on the antibacterial effects of calcium hydroxide. J Endod. 1998; 24: 663-5.

58. Siqueira Jr JF, Lopes HP. Mechanisms of antimicrobial activity of calcium hydroxide: a critical review. Int Endod J. 1999; 32: 361-9.

59. Siqueira Jr JF, de Uzeda M, Fonseca ME. A scanning electron microscopic evaluation of in vitro dentinal tubules penetration by selected anaerobic bacteria. J Endod. 1996; 22: 308-10.

60. Siqueira Jr JF, Lopes HP, de Uzeda M. Recontamination of coronally unsealed root canals medicated with camphorated paramonochlorophenol or calcium hydroxide pastes after saliva challenge. J Endod. 1998; 24 : $11-4$.

61. Siqueira Jr JF, Guimarães-Pinto T, Rôças IN. Effects of chemomechanical preparation with $2.5 \%$ sodium hypochlorite and intracanal medication with calcium hydroxide on cultivable bacteria in infected root canals. J Endod. 2007; 33: 800-5.

62. Sjögren U, Figdor D, Spångberg L, Sundqvist G. The antimicrobial effect of calcium hydroxide as a short-term intracanal dressing. Int Endod J. 1991; 24: 119-25. 
63. Soares JA, Leonardo MR, Silva LAB, Tanomaru Filho M, Ito IY. Effect of biomechanical preparation and calcium hydroxide pastes on the antisepsis of root canal systems in dogs. J Appl Oral Sci. 2005; 13: 93-100.

64. Sundqvist G. Ecology of the root canal flora. J Endod. 1992; 18: 427-30.

65. Tani-Ishii N, Wang CY, Tanner A, Stashenko P. Changes in root canal microbiota during the development of rat periapical lesions. Oral Microbiol Immunol. 1994; 9: 129-35.

66. Tanomaru JM, Leonardo MR, Tanomaru Filho M, Bonetti Filho I, Silva LA. Effect of different irrigation solutions and calcium hydroxide on bacterial LPS. Int Endod J. 2003; 36: 733-9.

67. Tronstad L, Andreasen JO, Hasselgren G, Kristerson L, Riis I. pH changes in dental tissues after root canal filling with calcium hydroxide. J Endod. 1981; 7: 17-21.

68. Vianna ME, Gomes BP, Sena NT, Zaia AA, Ferraz CC, de Souza Filho FJ. In vitro evaluation of the susceptibility of endodontic pathogens to calcium hydroxide combined with different vehicles. Braz Dent J. 2005; 16: 17580.

69. Zerella JA, Fouad AF, Spångberg LS. Effectiveness of a calcium hydroxide and chlorhexidine digluconate mixture as disinfectant during retreatment of failed endodontic cases. Oral Surg Oral Med Oral Pathol Oral Radiol Endod. 2005; 100: 756-61. 


\section{ANEXOS}

ANEXO 1 - Certificado do Comitê de Ética em Pesquisa em Seres Humanos da Faculdade de Odontologia de Araraquara - UNESP

Número do protocolo: 05/07

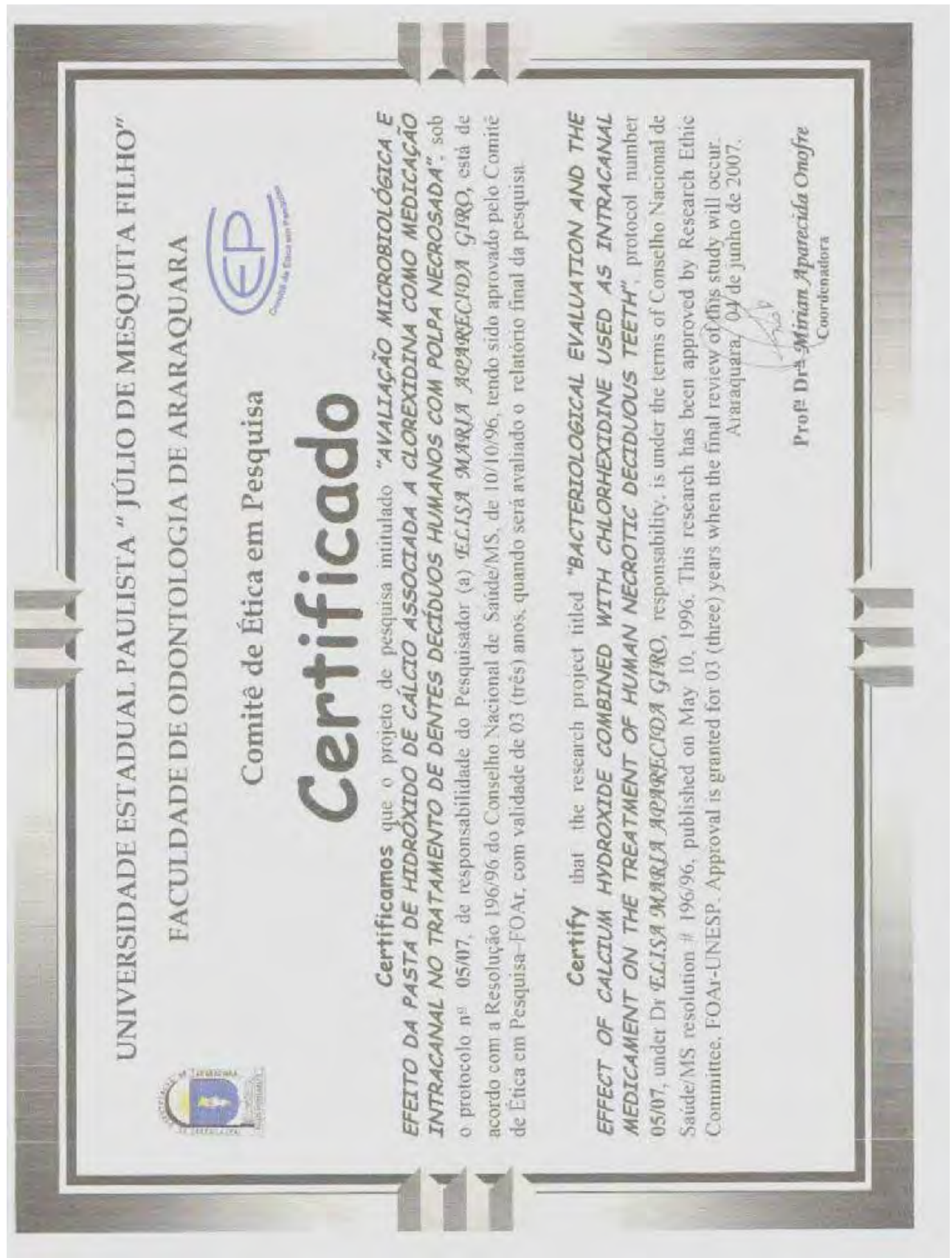


ANEXO 2 - Ficha elaborada para a realização das avaliações clínica e radiográfica

Nome:

Prontuário:

Endereço:

Cidade:

Telefone \#1:

Telefone \#2:

\section{Identificação:}

Idade:

Nascimento:

Recado:

Recado:

Pai:

Mãe:

Consulta 1 - Rx de diagnóstico, coleta microbiológica inicial, preparo biomecânico dos canais radiculares, coleta 2 , medicação intracanal, selamento do dente

\begin{tabular}{|l|l|l|l|l|l|l|l|l|}
\hline \multicolumn{1}{|c|}{ Data } & Dente & Mucosa & Dor & Fístula & Edema & Mobilidade & $\begin{array}{c}\text { Rarefação } \\
\text { óssea }\end{array}$ & $\begin{array}{c}\text { Reabsorção } \\
\text { radicular }\end{array}$ \\
\hline -__- & & & & & & & \\
\hline Diagnóstico: & $\begin{array}{l}(\quad) \text { Necrose pulpar, sem lesão periapical } \\
(\quad) \text { Necrose pulpar, com lesão periapical }\end{array}$ \\
\hline Grupo: & $\begin{array}{l}(\quad) \mathrm{Ca}(\mathrm{OH})_{2} \\
(\quad) \mathrm{Ca}(\mathrm{OH})_{2}+\mathrm{CHX} 2 \%\end{array}$ \\
\hline Observações: &
\end{tabular}

Consulta 2 - Remoção da medicação intracal, colocação de bola de algodão, selamento do dente

\begin{tabular}{|c|l|l|l|l|l|l|c|c|}
\hline Data & Dente & Mucosa & Dor & Fístula & Edema & Mobilidade & $\begin{array}{c}\text { Rarefação } \\
\text { óssea }\end{array}$ & $\begin{array}{c}\text { Reabsorção } \\
\text { radicular }\end{array}$ \\
\hline L__ & & & & & & & & \\
\hline Observações: & \multicolumn{10}{|l|}{} \\
\hline
\end{tabular}

Consulta 3 - Coleta 3 , obturação dos canais radiculares , restauração definitiva do dente, $\mathbf{R x}$

\begin{tabular}{|c|c|c|c|c|c|c|c|c|}
\hline Data & Dente & Mucosa & Dor & Fístula & Edema & Mobilidade & $\begin{array}{c}\text { Rarefação } \\
\text { óssea }\end{array}$ & $\begin{array}{c}\text { Reabsorção } \\
\text { radicular }\end{array}$ \\
\hline ___ & & & & & & & & \\
\hline Observações: & \multicolumn{10}{|l|}{} \\
\hline
\end{tabular}

Acompanhamento clínico e radiográfico - 1 mês

\begin{tabular}{|c|c|c|c|c|c|c|c|c|}
\hline Data & Dente & Mucosa & Dor & Fístula & Edema & Mobilidade & $\begin{array}{c}\text { Rarefação } \\
\text { óssea }\end{array}$ & $\begin{array}{c}\text { Reabsorção } \\
\text { radicular }\end{array}$ \\
\hline /__ & & & & & & & & \\
\hline Observações: & \multicolumn{10}{|l|}{} \\
\hline
\end{tabular}


Acompanhamento clínico e radiográfico - 3 meses

\begin{tabular}{|c|c|c|c|c|c|c|c|c|}
\hline Data & Dente & Mucosa & Dor & Fístula & Edema & Mobilidade & $\begin{array}{c}\text { Rarefação } \\
\text { óssea }\end{array}$ & $\begin{array}{c}\text { Reabsorção } \\
\text { radicular }\end{array}$ \\
\hline ___ & & & & & & & & \\
\hline Observações: & \multicolumn{10}{|l|}{} \\
\hline
\end{tabular}

Acompanhamento clínico e radiográfico - 6 meses

\begin{tabular}{|c|c|c|c|c|c|c|c|c|}
\hline Data & Dente & Mucosa & Dor & Fístula & Edema & Mobilidade & $\begin{array}{c}\text { Rarefação } \\
\text { óssea }\end{array}$ & $\begin{array}{c}\text { Reabsorção } \\
\text { radicular }\end{array}$ \\
\hline$-\_-$ & & & & & & & & \\
\hline Observações: & \multicolumn{10}{|l|}{} \\
\hline
\end{tabular}


Autorizo a reprodução deste trabalho.

(Direitos de publicação reservado ao autor)

Araraquara, 05 de março de 2010

JULIANA OLIVEIRA GONDIM 